OPEN ACCESS

Edited by: Duane Froese,

University of Alberta, Canada

Reviewed by:

Mary E. Edwards,

University of Southampton,

United Kingdom

Frederick Nelson,

Michigan State University,

United States

Vladimir Tumskoy,

Melnikov Permafrost Institute SB RAS,

Russia

*Correspondence:

Yuri Shur

yshur@alaska.edu

Specialty section: This article was submitted to

Cryospheric Sciences,

a section of the journal

Frontiers in Earth Science

Received: 13 August 2021 Accepted: 26 November 2021

Published: 12 January 2022

Citation:

Shur Y, Fortier D, Jorgenson MT, Kanevskiy M, Schirrmeister L,

Strauss $J$, Vasiliev $A$ and

Ward Jones M (2022) Yedoma Permafrost Genesis: Over 150 Years of Mystery and Controversy.

Front. Earth Sci. 9:757891.

doi: 10.3389/feart.2021.757891

\section{Yedoma Permafrost Genesis: Over 150 Years of Mystery and Controversy}

Yuri Shur $^{1 *}$, Daniel Fortier ${ }^{2}$, M. Torre Jorgenson ${ }^{1,3}$, Mikhail Kanevskiy $^{1}$, Lutz Schirrmeister ${ }^{4}$, Jens Strauss ${ }^{4}$, Alexander Vasiliev ${ }^{5}$ and Melissa Ward Jones ${ }^{1}$

${ }^{1}$ Institute of Northern Engineering, University of Alaska Fairbanks, Fairbanks, AK, United States, ${ }^{2}$ Geography Department, University of Montreal, Montreal, QC, Canada, ${ }^{3}$ Alaska Ecoscience, Fairbanks, AK, United States, ${ }^{4}$ Permafrost Research Section, Alfred Wegener Institute Helmholtz Centre for Polar and Marine Research, Potsdam, Germany, ${ }^{5}$ Earth Cryosphere Institute of Tyumen Scientific Center SB RAS, Tyumen, Russia

Since the discovery of frozen megafauna carcasses in Northern Siberia and Alaska in the early 1800s, the Yedoma phenomenon has attracted many Arctic explorers and scientists. Exposed along coastal and riverbank bluffs, Yedoma often appears as large masses of ice with some inclusions of sediment. The ground ice particularly mystified geologists and geographers, and they considered sediment within Yedoma exposures to be a secondary and unimportant component. Numerous scientists around the world tried to explain the origin of Yedoma for decades, even though some of them had never seen Yedoma in the field. The origin of massive ice in Yedoma has been attributed to buried surface ice (glaciers, snow, lake ice, and icings), intrusive ice (open system pingo), and finally to ice wedges. Proponents of the last hypothesis found it difficult to explain a vertical extent of ice wedges, which in some cases exceeds $40 \mathrm{~m}$. It took over 150 years of intense debates to understand the process of ice-wedge formation occurring simultaneously (syngenetically) with soil deposition and permafrost aggregation. This understanding was based on observations of the contemporary formation of syngenetic permafrost with ice wedges on the floodplains of Arctic rivers. It initially was concluded that Yedoma was a floodplain deposit, and it took several decades of debates to understand that Yedoma is of polygenetic origin. In this paper, we discuss the history of Yedoma studies from the early 19th century until the 1980s - the period when the main hypotheses of Yedoma origin were debated and developed.

Keywords: Yedoma, syngenetic permafrost, late Pleistocene, buried ice, ice wedges, mammoth, Northern Yakutia, Alaska

\section{INTRODUCTION}

The term "Yedoma" (Russian "Едома") was historically a folk name for flat hills with gentle slopes or remnants of terraces several dozen meters high (Murzaev, 1984). For scientific descriptions, this term was probably used for the first time by Figurin (1823) and was later introduced into the scientific literature by Birkengof (1933). Originally it was used as a geomorphic term to describe the remnants of terrain with ice-rich permafrost that formed in east Siberia during the late Pleistocene. According to Sher (1997), at least three different meanings of the term "Yedoma" now exist in the Russian literature: 1) a "Yedoma surface" in the geomorphic sense, 2) a "Yedoma Suite" in the stratigraphic sense, or 3) a cryolithological feature implying a special kind of frozen 
A

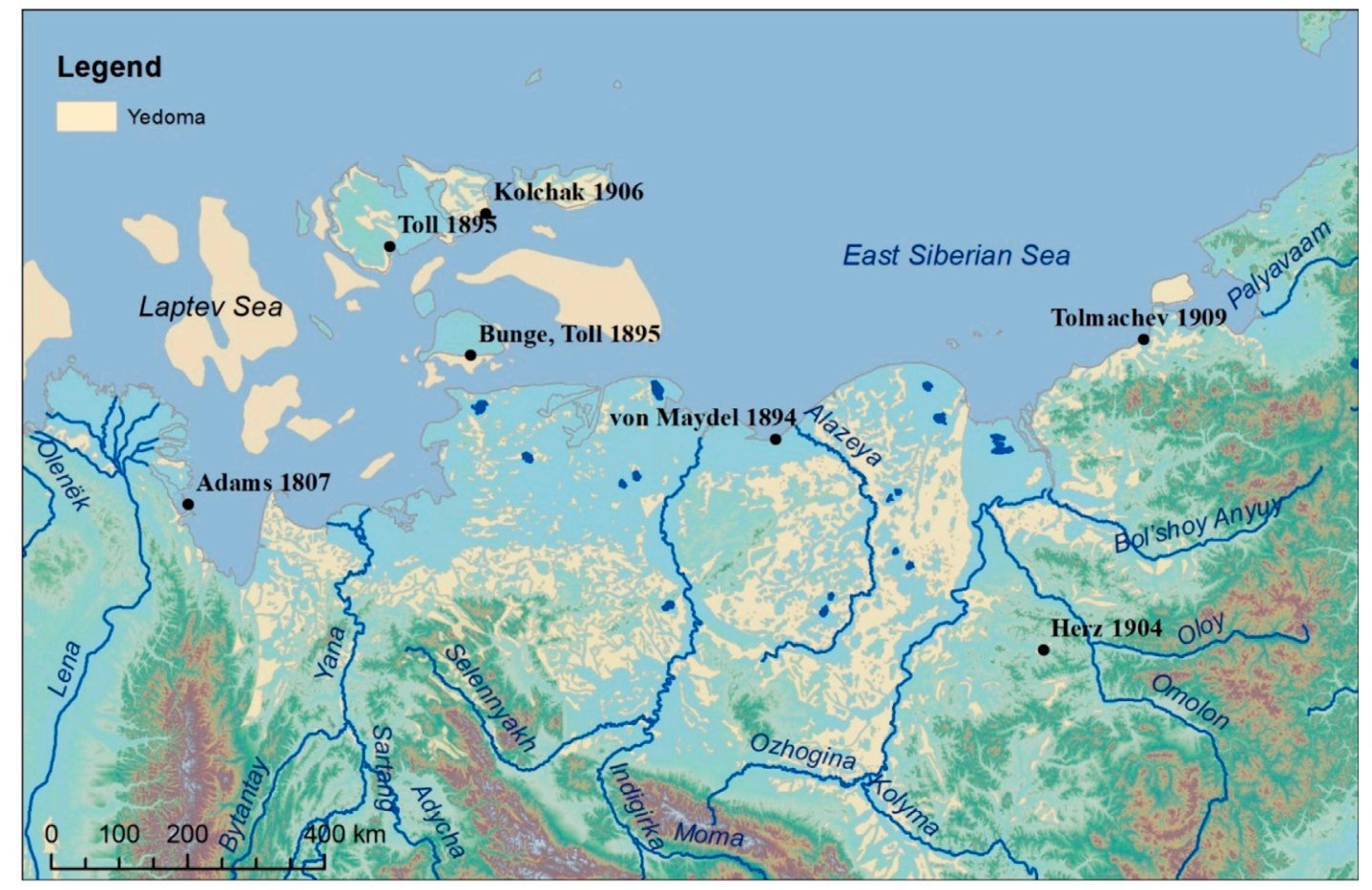

B

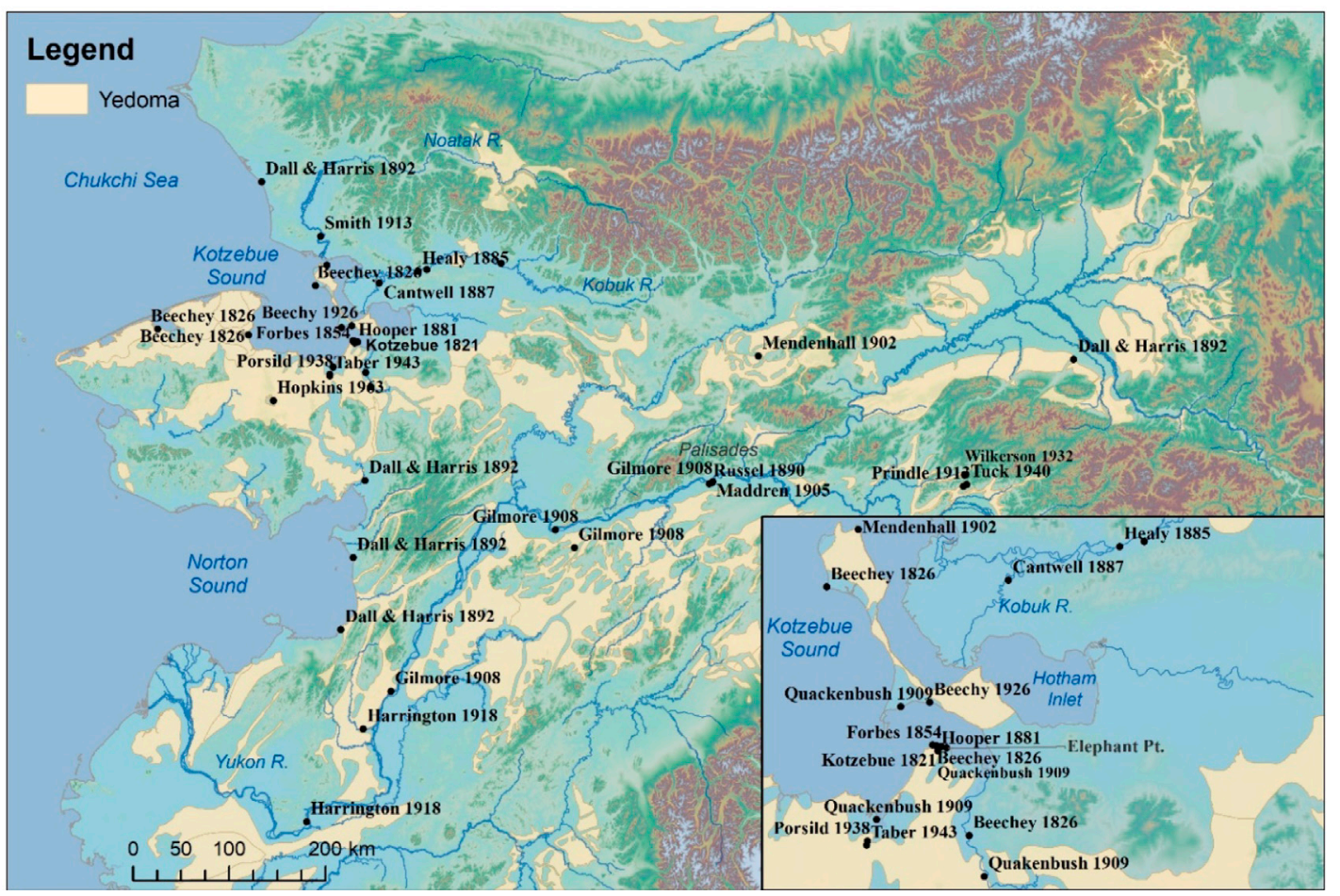

FIGURE 1 Maps of locations of the first Yedoma sites in Siberia (A) and Alaska (B), boundaries of Yedoma region are shown based on Strauss et al. (2021).

sediment, widely distributed in Beringia (area of land bounded by the Lena River in Russia to the west and the Mackenzie Delta in Canada to the east).

In this paper, we use the latter concept of Yedoma to characterize ice-rich silty deposits penetrated by large ice wedges, which resulted from sedimentation and syngenetic freezing in unglaciated areas amidst the last glaciation of the late Pleistocene (Schirrmeister et al., 2013 and references therein). We restrict the Yedoma formation to the late Pleistocene (post MIS five to the end of the last glaciation). 
Accumulation of sediment in a former harsh cold climate created this unique and fascinating permafrost type, which has little to no analog in contemporary permafrost formations. Yedoma is also an essential stock of ancient carbon and a treasure of information on the natural history and paleoclimate of Arctic and Subarctic in the late Pleistocene. Yedoma attracted a special interest of native people, explorers, and scientists because of its preservation of remnants of enormous number of extinct animals including mammoths. Since the sensational presentation of the first intact mammoth corpse to the scientific community by Adams in 1807, the interest in Yedoma has continued to grow until the present day.

For over 150 years, supportable hypotheses on Yedoma formation eluded scientists, but recent advances in permafrost science may now have solved the problem. In this paper, we review the history and locations of early Yedoma observations, compare the various explanations that were proposed for its genesis and ice origins, and highlight some of the controversies among scientists defending their ideas.

\section{FIRST YEDOMA FINDING IN SIBERIA}

Yedoma, or late-Pleistocene Ice Complex has been known to native people of northeast Siberia and northwest Alaska for centuries. They associated Yedoma with the location of fossil remnants of "prehistoric" animals and looked for it as a source of mammoth tusks. Historically, the ivory market has been enormous, and numerous hunters and traders ("promyshlenniks" in Russia) have scoured the shores of Arctic seas and rivers to find mammoth tusks. Wrangel (1841) mentioned that in 1821 one fossil bone "hunter" brought $8,000 \mathrm{~kg}$ of tusks of perfect quality from the New Siberian Islands. He also noted that collectors found the biggest and best tusks on these islands, with smaller quantities located on the northern shore of the Laptev Sea and more seldom findings in southern parts of Siberia. von Toll (1959) mentioned that tusks hunters looked specifically for baydzherakhs (tall conical thermokarst mounds) to find the best quality ivory.

An interest in Yedoma within the scientific community was triggered in the beginning of the 19th century by two findings, one in Russia and the other in Alaska. In Russia, a young biologist named Michael Adams, employed as an adjunct in zoology at the Russian Academy of Sciences, was in Yakutsk in June 1806. A merchant told him that the Tungusian chief Shoumakhov had discovered a whole mammoth carcass on the shore of the Bykovskiy Peninsula (Figure 1). Adams was fascinated with the news (Supplementary Quote S1 in the supplement); he immediately set off on his journey and in a few weeks reached the mammoth site, assisted by Shoumakhov and a crew of 14 people. Adams $(1807,1808)$ described in detail how Shoumakhov had found an unusually large chunk of ice that separated from the ice cliff in 1799. The following year, Shoumakhov saw two feet of a mammoth revealed from melting ice. It took almost 3 years for the mammoth body to melt free from the ice. In 1804, the Russian merchant Roman Boltunov drew the first sketch of the mammoth. Copies of his sketch made at the time (Figure 2A) were sent to Johann Friedrich Blumenbach in Göttingen and Georges Cuvier in Paris. Notes made on the sketch in Blumenbach's handwriting states: "Elephas primigenius in Russia, called mammoth, excavated with skin and hair 1806 in June at the outflow of the Lena into the Arctic Ocean. Roughly drawn as it was found mutilated and filthy." The other notes at the top right of the drawing are from Wilhelm Moritz Keferstein (1833-1870).

When Adams reached the mammoth site, the flesh and internal organs of the mammoth had been eaten by wild animals, but he gathered nearly the entire skeleton as well as some skin and fur. In Yakutsk, Adams bought two mammoth tusks (Shoumakhov earlier had sold the original tusks to Boltunov for 50 rubles) and brought his mammoth to Saint Petersburg where it was reassembled and is on display in the Museum of Zoology (Figure 2B). Adams' discovery of the first mammoth skeleton was a world sensation, and his publication was quickly translated into several languages.

Adams described the coastal exposure at the mammoth's location having a clear ice with a nauseating smell. He estimated that the exposure was $3 \mathrm{~km}$ long and 60-80 $\mathrm{m}$ high. von Baer (1842) thought that this description was an exaggeration. It is unclear how Adams could have evaluated the size of the bluff because at the time of his visit the exposed part of the bluff was 100 steps from the mammoth's position and 160 steps from the sea. The ice was covered by moss and a $50-\mathrm{cm}$-thick layer of soil that was partially frozen. Adams described mudflows slowly moving towards the sea; he also mentioned soil wedges among ice (Supplementary Quote S2).

From the permafrost science point of view, Adams' description of the site was rather disappointing; it is less than one page, and his explanations are difficult even for people familiar with Yedoma to understand. von Baer (1842) tried to make sense of Adams' short description but failed, blaming inaccuracies in Adams' paper (Supplementary Quote S3). von Middendorff (1860) noted that Adams' description of the site was unsatisfactory and not trustworthy. von Toll (1897) also found that the explanations in Adams' short description were unsatisfactory and unclear.

Adams' descriptions of the soil and ground ice are confusing. In some translations of his report, originally published in French in 1807, soil wedges were described as lumps or strips of eroded soil among ice floes. Some authors quoting Adams even omitted soil wedges in ice as unimportant detail. Nevertheless, there is a possibility that Adams wrote about soil wedges inside the ice of the exposure itself. Leffingwell (1919) in his short abstract of Adams' paper said: "The mammoth remains were found in the earth wedges between the ice masses." This interpretation is also consistent with the picture (Figure 3) drawn by von Toll (1897) who tried to reconstruct what Adams had potentially seen and used it as proof for his own ideas.

With our contemporary knowledge, we interpret Adams' description of the site as: 1) the cliff was not eroded by the sea at the time when Shoumakhov found the mammoth; 2) the cliff was affected by thermal denudation and therefore was not vertical; and 3) the mammoth slid downslope from the site where it thawed out. Overall, the main message gained from this site in the Russian Arctic was the existence of perennially frozen soil 

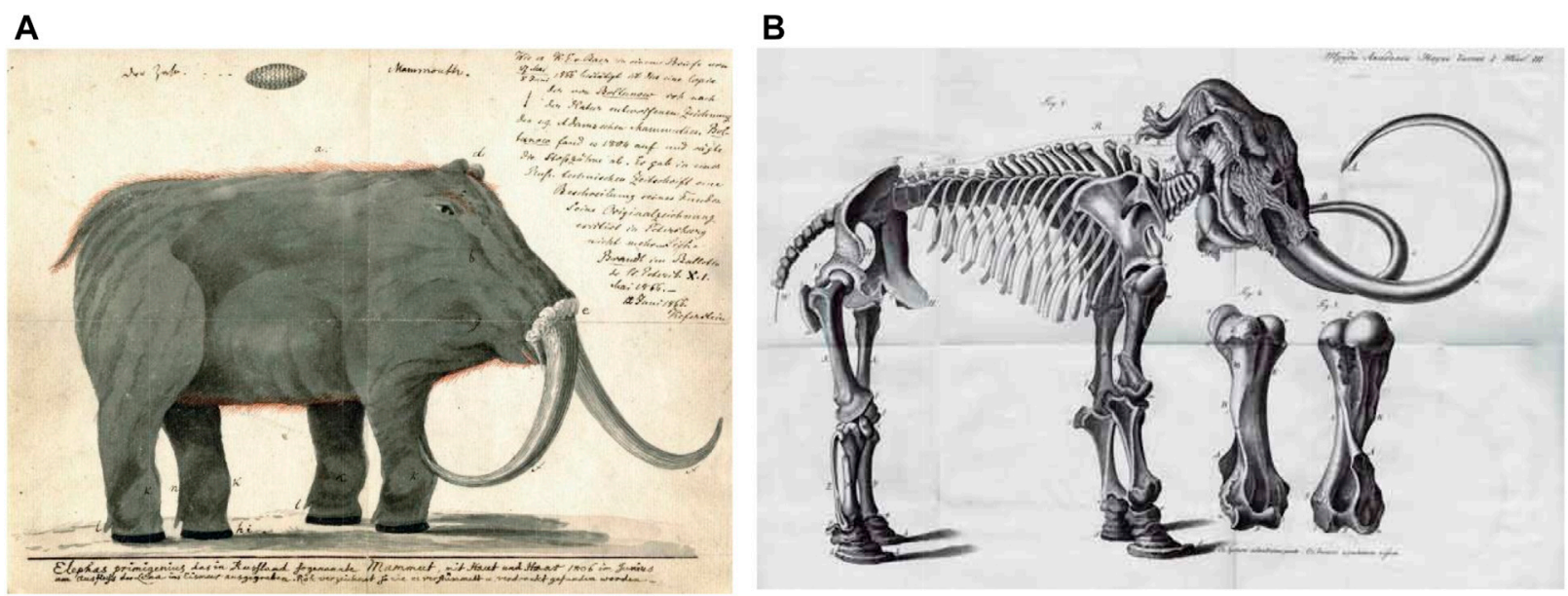

FIGURE 2 | (A) - The world's first reconstruction drawing of a mummified carcass of the so-called "Adams or Lena Mammoth" based on the original sketch by Roman Boltunov (in the Ethnological Collection of the University of Göttingen); (B) - Wilhelm Gottlieb Tilesius' etching of the Adams mammoth skeleton (now on display in the Museum of Zoology, Sankt-Peterburg).

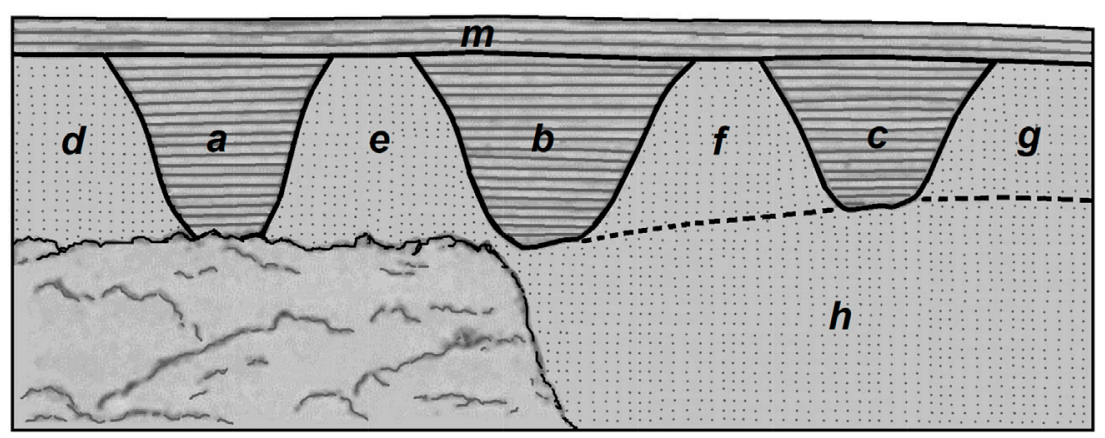

FIGURE 3 | von Toll (1897) perception of Adams (1808) description of a Yedoma cliff in Bykovskiy Peninsula; a, b, c-mineral soil; d, e, f, g, h-ice; m-surficial organic material.

containing large bodies of ground ice and the remnants of mammoths.

\section{FIRST YEDOMA FINDING IN ALASKA}

Ten years after Adams' discovery, the Russian ship "Rurik," commanded by Captain Otto von Kotzebue, sailed along the shores of northwest Alaska. On August 8, 1816, the crew found a high exposure of ground ice onshore (Figure 1). von Kotzebue (1821) described a remarkable finding made by Dr. Eschscholtz who discovered large masses of pure ice in the 30-m-high coastal bluff. To commemorate this remarkable discovery, von Kotzebue named the bay after Dr. Eschscholtz (Supplementary Quote S4). Von Kotzebue mentioned numerous mammoths' teeth and bones exposed at this place; he also provided the latitude $\left(66^{\circ} 15^{\prime} 36^{\prime \prime} \mathrm{N}\right)$ that helped later explorers to find the site.

Adelbert von Chamisso (1821), a scientist of von Kotzebue's crew, provided additional descriptions of the exposure in
Eschscholtz Bay and compared it to other locations in northern Asia and North America, including the site of Adams' mammoth discovery (Supplementary Quote S5). Ludwig Choris (1822), an artist in von Kotzebue's crew, created two paintings of the exposure (Figure 4). In Figure 4A, stripes of ice are seen that can be recognized as ice wedges, which in the middle of summer are commonly protruding outward relief relative to the columns of dark icerich soil that thaws faster than ice. Figure 4B shows the exposure at a larger scale, where bodies of ice that are several meters wide are divided by columns of soil.

\section{EMERGING INTEREST AFTER THE FIRST YEDOMA FINDINGS BY ADAMS AND VON KOTZEBUE}

For the scientific community, the first Yedoma findings were a sensation. For over 150 years since the works by von Kotzebue 

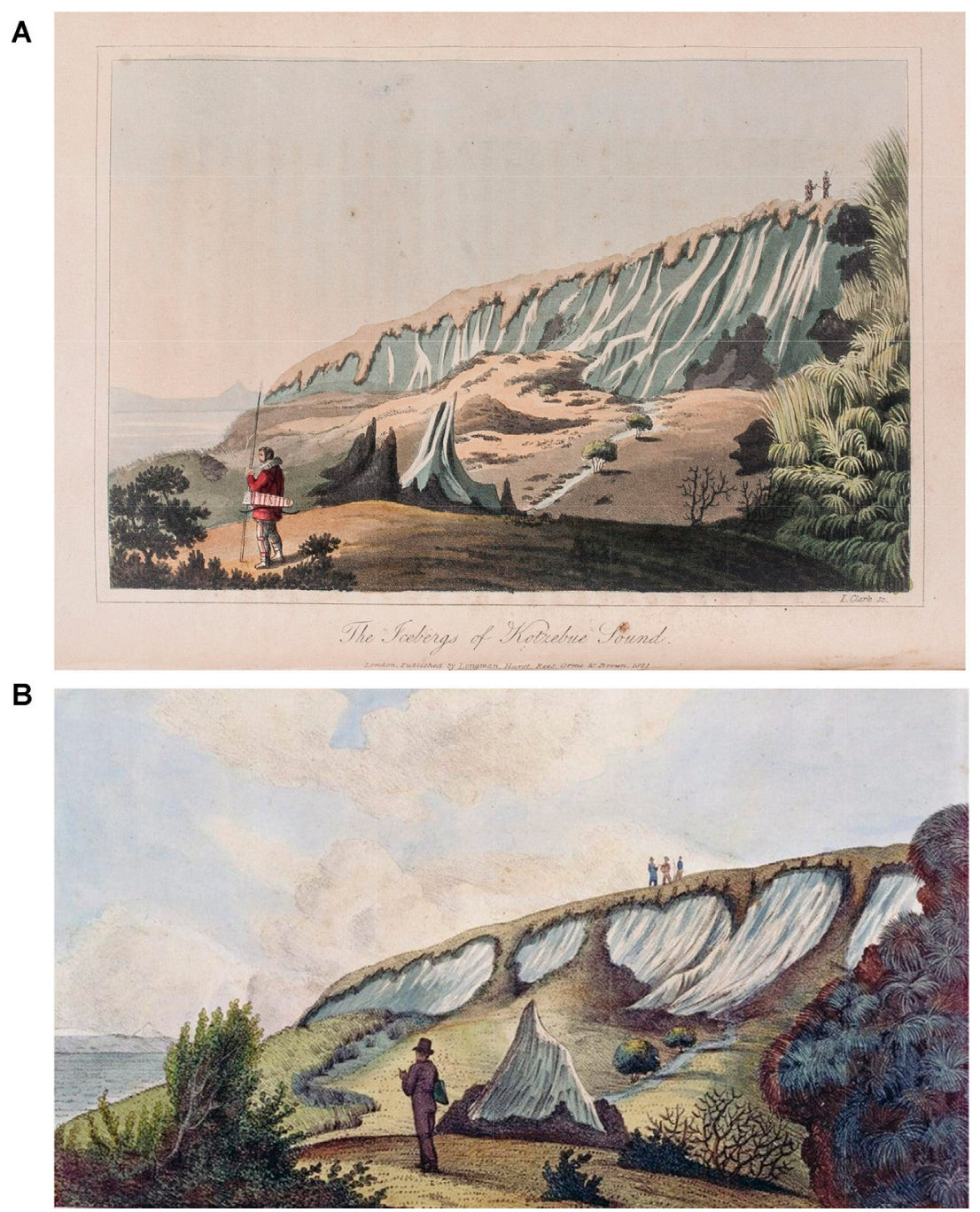

FIGURE 4 | Paintings "The icebergs of Kotzebue Sound" (A) and "Vue des Glaces dans le Golfe de Kotzebue (View of the Glaciers of the Gulf of Kotzebue)" (B) by Ludwig Choris (1822).

and Adams, attempts to determine the genesis of Yedoma have mainly been focused on the origin of the bodies of massive ice. Soil in Yedoma was often unnoticed or described as a secondary feature filling cavities made by erosion within the massive ice. Discussions focusing on the genesis of ice rather than the origin of the entire formation prevailed until the 1950s.

\section{Alaska}

In July 1826, 10 years after von Kotzebue's voyage, Captain Frederic W. Beechey and his crew revisited the site described by von Kotzebue (1821). After observation of the exposure from the boat and a brief inspection it by Mr. Collie, Beechey (1831) concluded that ice was just a coating on the bluff face and the ice was a product of snowdrift or freezing of water running over the surface of the cliff (Supplementary Quote S6). With such a perception, in September 1826, Captain Beechey looked at a similar exposure at Cape Blossom on the Baldwin Peninsula (Figure 1), which Beechey named after his ship (Supplementary
Quote S7). The description by Beechey (1831) showed that in front of him was an exposure of ice wedges with intermittent soil columns. He explain ice as imbedded in the indentations in soil of the cliff. Most likely, he misinterpreted the origin of the ground ice in the exposure because he already had made up his mind before closely examining these features.

von Chamisso (1836), a crew member of von Kotzebue's expedition, rejected Beechey's conclusions, and insisted on the accuracy of von Kotzebue's report (von Chamisso, 1821) that described the occurrence of ice as a thick solid body (Supplementary Quote S8).

Beechey's crew members A. Collie and Lieutenant E. Belcher provided their opinions on the genesis of the ice (see Table 1 for different hypotheses on the genesis of massive ground ice within Yedoma). Collie described three possible mechanisms of ground ice formation: 1) from snowdrifts converted into ice by successive thawing and freezing in spring and summer; 2) from water collected in deep fissures and cavities; and 3) from water 
TABLE 1 | Hypotheses of the genesis of massive ground ice and respective authors.

Genesis of ice
Ice coatings on the surface of exposure
Glacier or ice sheet
Infiltration ice
Buried lake ice
Icing
Open system pingo
Firn and snow
Segregated ice
Wedge ice

Genesis of ice

Author
Beechey (1831)
Hooper (1884), Herz (1904), Muir (1917), Obruchev (1931), Saks (1947)
Belcher (Beechey, 1831)
Dall (1881), Russell (1890), Turner (1886), Mendenhall (1902), Maddren (1905), Grigoriev (1927)
Tyrrell (1917), Wilkerson (1932), Gusev (1958)
Porsild (1938)
Dawson (1894), Geikie (1894), von Toll (1897), Grigoriev (1927), Tolmachev (1903), Ermolaev (1932), Gorodkov (1948),
Grave (1944), Gusev (1958)
Taber (1943)
Figurin (1823), von Bunge (1887), Leffingwell (1919), Popov (1952)

trickling from the slope above the frozen bluffs. Belcher proposed a hypothesis that water infiltrates every summer to the surface of the frozen soil, where it freezes, and accumulates into a thick horizontal sheet of pure transparent ice (Beechey, 1831).

\section{Russia}

In northern Yakutia, Dr. A. E. Figurin, a physician in Anzhu's expedition to the New Siberian Archipelago (1820-1824), observed numerous exposures of muddy ice along Siberian rivers, creeks and seashores of the mainland and islands. The ice mostly had the shape of wedges narrowing to their base. When describing the tundra terrain, he defined Yedoma as hills that appeared almost everywhere and at many places contained ice wedges. The Yedoma surface was covered by tussocks and bare, "mold-covered" spots (Figurin, 1823), which we interpret as frost boils. Figurin also described the formation of 'buyarakhs', which are known as baydzherakhs (conical thermokarst mounds typical of Yedoma) in the modern permafrost literature (van Everdingen, 1998). Figurin's major contribution to permafrost science was the first explanation of the formation of ice wedges caused by frost cracking (Supplementary Quote S9).

In his "Excerpts on Siberia," Mathias von Hedenström (1830) also described ice wedges and tried to explain the origin of alternating horizontal layers of ice and soils that he had observed in exposed bluffs of the Yana-Kolyma region of Northern Yakutia. He mentioned that ice wedges sometimes cross these horizontal layers (Supplementary Quote S10).

\section{CONTINUING STUDIES IN ALASKA DURING THE 19TH CENTURY}

In 1848, Eschscholtz Bay was visited by the ship "Herald" under the command of Captain Henry Kellett in search of the lost Franklin Expedition. The results of the expedition were reported in several volumes covering a general narrative of the cruise as well as the botany and zoology studied at the sites they visited (Seemann, 1853). Ice cliffs in Eschscholtz Bay were described in every volume, but in more detail in the volume on zoology written by the prominent British naturalist Sir John Richardson (1854). He was not part of the crew, however, and his extensive description is based on notes taken by members of the expedition, including $\mathrm{H}$. Kellett, B. Seemann, and J. Goodridge. Richardson (1854) concluded that von Kotzebue (1821) was right about the ice originating as a "solid iceberg" and Beechey (1831) was wrong about the ice in bluff being a superficial coating of water freezing to the bluff face (Supplementary Quote S11). However, the issue of relating mammoth remains to a thin layer of soil covering ice remained a problem for Richardson (Supplementary Quote S12). Seemann (1853) also concluded that Captain Beechey was wrong in his explanation of the ice being just a coating on the face of the bluff and critically assessed the hypothesis of Belcher who assumed that surface water penetrated through peat and clay and that ice accumulated gradually (Supplementary Quote S13).

From the descriptions of several exposures based on notes by Goodridge, it is difficult for us to reconstruct the structure of the bluffs, Goodridge tended to interpret exposures as made of ice, describing one of exposures as "a few icy pillars and detached walls standing twenty feet above the surrounding level surface, and still covered with from seven to ten feet of soil." A description of the cliff is also illustrated by a painting (Figure 5), produced by artist W. Fitch from a sketch made by one of the members of the expedition. It would be especially interesting to see this original sketch. In the painting, the exposure is presented as a pure ice with a thin layer of clay and peat over ice.

Kellett and Richardson, who reviewed notes taken by Kellett and two of his companions, discussed several modes for the ice formation and did not come to a credible conclusion. It is interesting that they took literally von Kotzebue's definition "iceberg," while von Kotzebue and von Chamisso did not discuss the mode of ice formation. We think that von Kotzebue used the word "iceberg" just to describe an ice mountain (as "berg" means mountain in German) without any relation to real icebergs. In his memoir on the voyage, von Chamisso mentioned "so-called iceberg" (von Chamisso, 1836).

Dall (1881) visited Eschscholtz Bay in 1880 and compiled detailed descriptions of the exposed bluff. Among other interesting details, he mentioned that the solid ice was penetrated by deep vertical holes, in which organic-rich sediments had been deposited in layers, and appeared as soil cylinders on the exposed face of the bluff (Supplementary Quote S14).

In evaluating earlier hypotheses of ice genesis, Dall and Harris (1892) concluded that von Kotzebue and Eschscholtz (von Kotzebue, 1821) were right in their interpretation of the ice formation and that Beechey (1831), who thought that the ice 


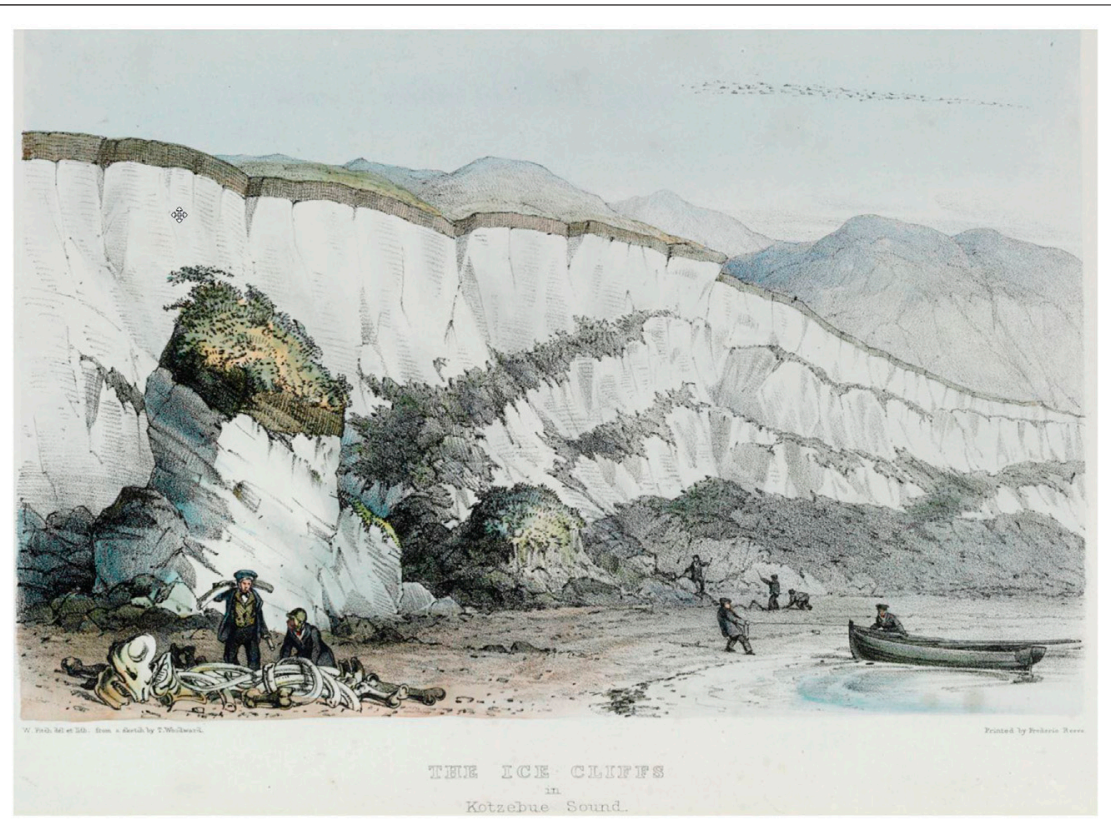

FIGURE 5 | Painting "The Ice Cliffs in Kotzebue Sound" by the artist W.W. Fitch painted from a sketch made by T. Woodward, one of the members of the expedition. Second half of the 19th century (Museum National d'Histoire Naturelle, Paris).

was a superficial deposit, was wrong (Supplementary Quote S15). Given the limitations of earlier explanations, Dall and Harris (1892) developed an elaborate regional scheme for relating an episode of ice formation to changing water levels in the Bering Sea and depositional processes in the surrounding area. They envisioned a land connection or enormous level plain covering much of the present area of the Bering Sea related to uplift of the area during the Miocene (Supplementary Quote S16), somewhat the reverse of the land connection caused by lowering of sea level associated with glaciation during the Pleistocene, as currently accepted. While the enormity of fluvial processes creating such widespread deposits is unimaginable given current knowledge, the hypothesis at least sought to address the widespread nature of the deposits, provided a link between ice accumulation and depositional process, and related ice accumulation to development of surface vegetation and soils.

Captain C. L. Hooper (1884) commanding the Revenue Cutter “Thomas Corwin" visited Eschscholtz Bay and Elephant Point near the mouth of the Buckland River in 1880 and 1881 . He examined the ice and also found that the explanation given by Beechey was not correct. Hooper made several valuable observations and suggested wedge-ice origin of some of the massive ice bodies (Supplementary Quote S17).

John Muir (1917), a member of Hooper's expeditions, defined the massive ice at Elephant Point as buried glacier ice but he also noticed masses of dirty stratified ice of a different origin (Supplementary Quote S18).

John C. Cantwell (1887), Lieutenant on the U.S. Revenue Marine steamer "Corwin," described the occurrence of a chain of exposed ice cliffs up to 150 feet high along the Kobuk (Kowak) River starting about $130 \mathrm{~km}$ from the mouth (Figure 6)
(Supplementary Quote S19). Cantwell (1896) speculated that maybe it was an old glacier buried beneath the deposits of a more recent inundation, but finally he admitted: "The formation of the remarkable ice cliffs in the lower country is, however, a geological nut which the writer admits his inability to crack."

Findings of Yedoma in Eschscholtz Bay, on the Baldwin Peninsula, and along the Kobuk and Buckland rivers showed vast areas surrounding Kotzebue Sound that were, and in some places still are, underlain by Yedoma, which for thousands of years has been eroded by the sea and rivers. This allows us to hypothesize that Eschscholtz Bay, Selawik Lake, and Hotham Inlet are results of thermokarst processes that have affected original Yedoma. Combined with lagoonal intermediate stages, erosion has formed the modern landscape leaving Yedoma remnants.

Turner (1886) studied the environment of Western Alaska from 1874 to 1881 and tried to explain the origin of the ice bluffs that had been observed at various parts of the coast, especially north of the Bering Strait. He described a hypothetical formation of a thick body of ice resulting from continuous covering of lakes with floating vegetation mats, whose thermal properties protect the ice underneath it from melting during the summer (Supplementary Quote S20). Another important factor supporting rapid freezing was a thin layer of snow. Turner evidently was the first to suggest a lacustrine origin for the massive ice exposed in the Yedoma bluffs.

Russell (1890), who made a reconnaissance of the Yukon River for the United States Geological Survey (USGS), visited the Palisades Bluff (Figure 1B) and came to the similar idea that the massive ice in these famous bluffs had a lacustrine origin (Supplementary Quote S21). Russell's work is of a special interest to permafrost science because it appears that he was the first to 

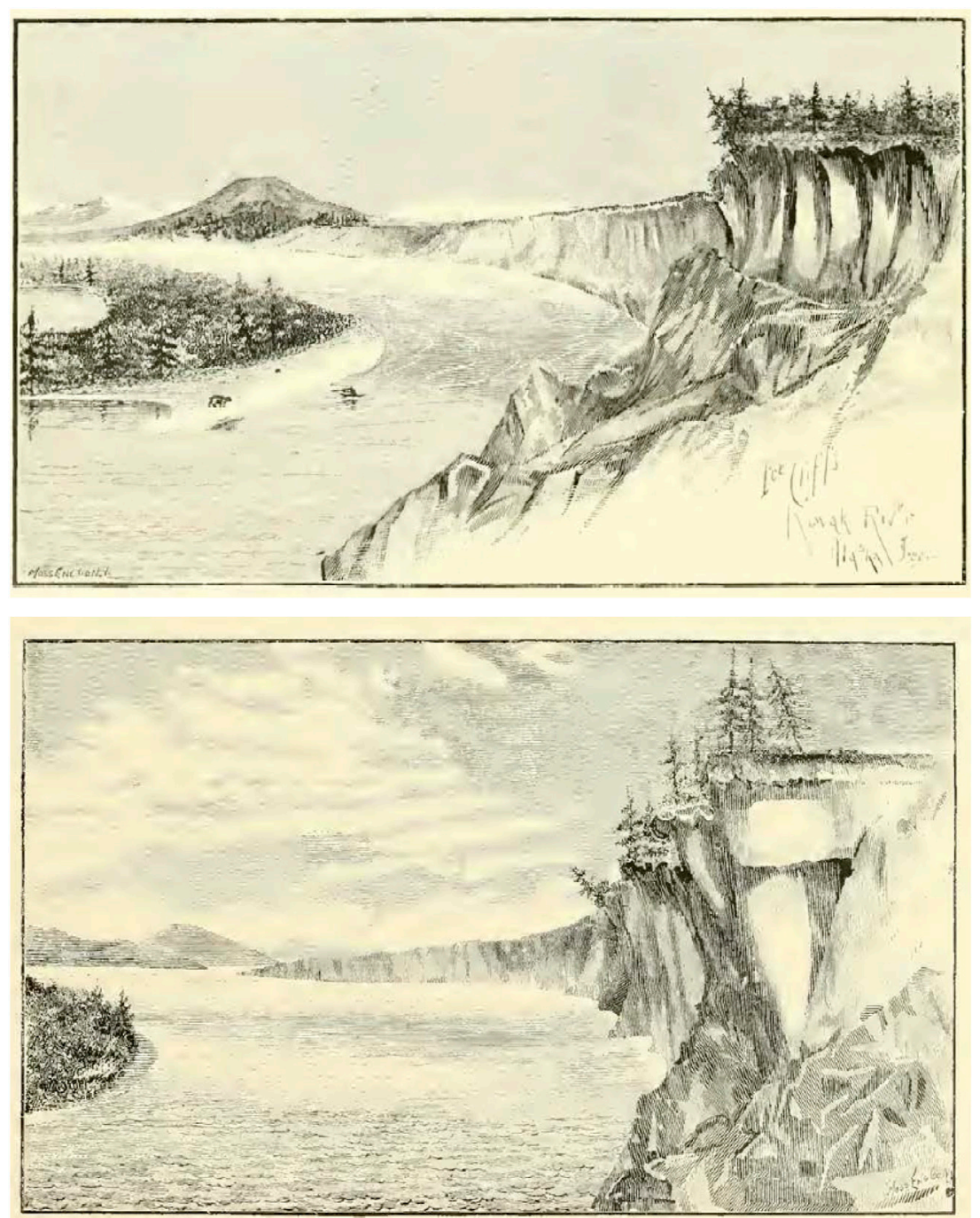

FIGURE 6 | Ice cliffs at the Kobuk River (Cantwell, 1887).

clearly define the process of syngenetic permafrost formation, presuming that under certain conditions deposition and freezing may occur at the same time, which explains the formation of alternating layers of clear ice and soil (Supplementary Quote S22).

While crediting Russell (1890) for a clear understanding of syngenetic permafrost formation, we also note that prior to Russel (1890), Lopatin (1876) had described the formation of interbedded ice and sand layers in the winter of 1868 on the Okhotsk Sea coast of the Sakhalin Island. In observing that the surface layers are frozen in winter and thaw during summer, Lopatin presumed that under colder climate these ice layers may be preserved for centuries (Supplementary Quote S23). He believed that the ice-rich soil he had described in the Yenisey River Delta could form in a similar way. Dall and Harris (1892) shared the opinions of Turner (1886) and Russell (1890) relating the origin of ice in the cliffs to frozen lakes buried by soil.

Dawson, the Director of the Geological Survey of Canada (1894) generally agreed with Dall and Harris (1892) on the timing of ice formation and the environmental conditions but thought that the ice was a result of snow accumulation. Soil, which was derived from adjacent highlands and deposited by rivers, covered ice and protected it from thawing.

Mendenhall (1902), who made a geological reconnaissance along the Yukon, Kanuti, and Kobuk rivers for the USGS, observed Yedoma exposures along the Kobuk (Kowak) River and Eschscholtz Bay and agreed with Russell (1890) that the ice originated from a frozen lake (Supplementary Quote S24).

\section{THE SCIENTIFIC AND PERSONAL CONFRONTATION BETWEEN EDUARD VON TOLL AND ALEXANDER VON BUNGE}

Although numerous hypotheses on the origin of Yedoma ice had been proposed since the initial discoveries by Adams (1808) and von Kotzebue (1821), the first serious discussion on the real origin 
of the massive ice within Yedoma took place between von Toll $(1895,1897)$ and von Bunge $(1883,1895)$ at the end of 19th century. These two prominent Arctic explorers were members of the same polar expeditions and talked about the same exposures on the northern shores of Yakutia, including the New Siberian Islands, but came to different conclusions on the origin of Yedoma ice. Their disagreement even took on a personal character. von Toll (1895) wrote an extensive paper, in which one of the main points was to prove that he was right, and von Bunge was wrong. According to von Bunge (1903), von Toll subjected von Bunge's hypothesis to "strict scientific criticism, calling it a "theory" without any reason."

\section{Von Bunge's Theory}

Von Bunge (1887) witnessed the formation of frost cracks accompanied by a loud noise "like shots under the surface remaining a distant cannonade," like earlier observations made by Figurin (1823). Von Bunge noted that the cracks penetrated to significant depth. The tundra he observed on the Lena Delta was divided into a myriad of irregular polygons, whose edges were higher than the center. Between the edges of neighboring polygons, there was a narrow trough, which often was used as a path by lemmings. This trough corresponded to a deep crack in the earth filled with ice. Von Bunge speculated that when the spring snowmelt water fills the cracks, it freezes, expands with tremendous pressure and pushes the walls of the crevices apart. By repeated cracking and freezing of snowmelt water, the ice volume around cracks becomes bigger over time.

From his observations of the formation, von Bunge (1895) concluded that huge masses of ice could be formed in this manner. He correctly described the morphology of Yedoma and the nature of ice but found it hard to comprehend how frost cracks could penetrate several dozens of meters in depth and develop the increased width of wedge ice at great depths. He found that an ice wedge, when exposed in coastal bluffs, could present an appearance of a continuous horizontal layer of ice. He also explained the impurities of ice (foliations) and the decrease in the size of ice crystals with depth. Given current knowledge, it is easy to find limitations in von Bunge's descriptions and conclusions, but at the time of his studies he made a significant contribution to our understanding of Yedoma ice formation.

\section{Von Toll's Theory}

In contrast, von Toll $(1891,1895)$ considered the masses of ice on Bol'shoy Lyakhovsky Island as the remnants of a mainland glacier assumed to have covered these islands, as well as the coasts of the continental Siberia from the Khara-Ulakh Ridge to the Chaun Bay (von Maydel, 1894) and extended $200 \mathrm{~km}$ south into the mainland. He stated: "No one geologist, looking at such an exposure, would have any reservation that the ice is older than the cracks filled with layers of ice and clay" (in Obruchev (1892) translation of von Toll (1891) paper). However, according to von Bunge (1903), von Toll had not seen Yedoma exposures during the summer when they were not covered with snow. He was relying instead on the outstanding photographs of Yedoma (e.g., Figure 7) given to him by von Bunge (von Toll, 1895)
(Supplementary Quotes S25, 26). Von Toll's own photographs show only a slope covered by snow with just the tops of baydzherakhs visible on the surface. In his publications, von Toll described exposures of the southern shore of Bol'shoy Lyakhovsky Island near the mouth of the Vankina River (Supplementary Quote S25) based on the photograph by von Bunge (Figure 7, bottom). Von Toll studied crystals of ice taken from the upper part of an exposure. He concluded that "the structure of Quaternary ice layers on the New Siberian Islands speaks in favor of their origin from snow and strongly against the water origin." According to von Toll, the firn had remained at temperature below $0^{\circ} \mathrm{C}$ the entire time before it was covered with soil, and the growth of ice crystals was not possible (Supplementary Quote S27).

\section{Von Toll-von Bunge Disagreement}

According to von Toll, von Bunge described his idea for the first time in letters to Shrenk (von Bunge, 1887) and they were written in the winter of 1884 in Sagastyr during a few hours of rest in the midst of hard work, and in a difficult environment, therefore could not contribute to a strictly scientific treatment of the subject. In any case, he said that von Bunge was wrong in his explanation of the massive ice origin and did not solve the problem of the origin of ice that was presented to him. von Bunge (1903) answered von Toll's criticisms (Supplementary Quotes S28, 29), emphasizing that von Toll did not see the exposures in the summertime and arguing that by no means the ice could be older than the soil. Although von Bunge was certain of his hypothesis of the formation of ice, he admitted that the problem of the soil and ice origin was very complicated and that future researchers would solve it.

In 1903, while searching for the vanished group of von Toll, Kolchak (1906) visited Faddeevskiy Island where he described 70-80 feet (20-25 m) exposure of Yedoma as a glacier covered with soil and "typical cones of baydzherakhs." He was the first to describe remnants of Yedoma under water along the seafloor (Supplementary Quote S30).

\section{CONSEQUENCES OF THE VON TOLL - VON BUNGE DISAGREEMENT ON YEDOMA STUDIES IN RUSSIA IN THE 20TH CENTURY}

Summarizing the von Bunge-von Toll disagreement, we can conclude that von Bunge recognized that the focus of studies should have been the soil, while von Toll and others were preoccupied with the ice. Popov (1952) later said that both von Toll and von Bunge were not correct because soil and ice formed simultaneously (syngenetically). We agree with von Bunge that the soil is the primary substance, as the existence of soil sets conditions needed for ice formation.

Nevertheless, for the next 50 years, the majority of leading Russian scientists unequivocally supported von Toll in his dispute with von Bunge. In the introduction of the Russian translation of von Toll's diary (1959) from his voyage on the yacht "Zaria," 

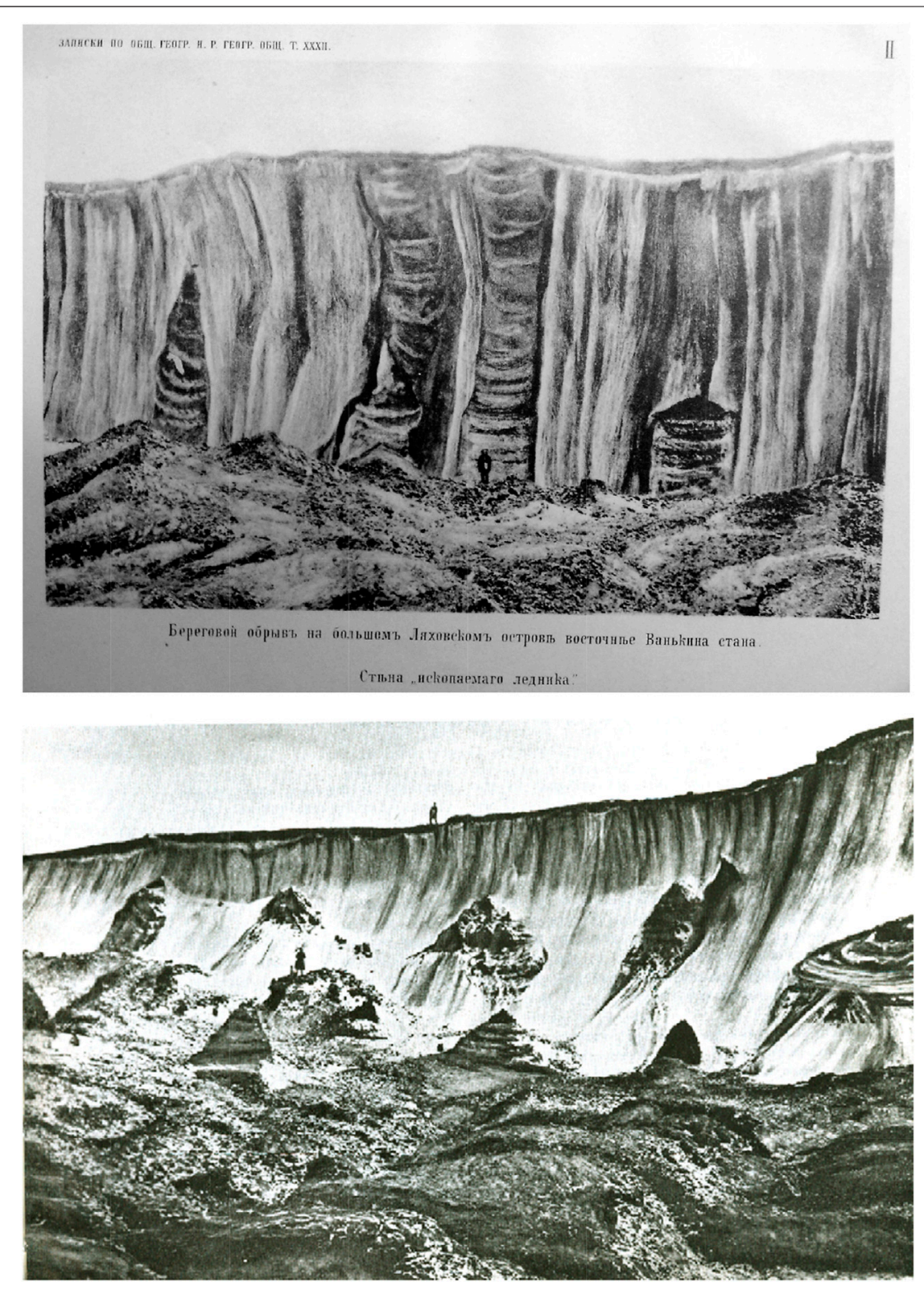

FIGURE 7 | Southern coast of Bol'shoy Lyakhovsky Island, Vankina River mouth, photographs by von Bunge (von Toll, 1897).

Wittenburg (1959), a prominent Arctic geologist, wrote: "von Toll's studies of fossil ice on Bol'shoy Lyakhovsky Island have not been outshined to date. They are included in every textbook on geology and physical geography and translated into many languages."

Many Russian scientists supported von Toll's concepts of buried glacial ice, or at least firn. In 1901, an expedition of the Russian Academy of Sciences recovered a mammoth on the bank of the Berezovka River, a tributary of the Kolyma River. A short description of the site was done by a zoologist, O.F. Herz (1904), as the geologist who was assigned to the trip did not participate. Herz took a photograph of the exposure (Figure 8), collected cores of ground ice from the site and ultimately supported a glacial origin of the ice (Supplementary Quote S31).

Tolmachev (1903) studied the samples of ice collected by Herz and evaluated their properties, such as unit weight, crystal size and shape, and air bubbles within the ice. Tolmachev stated that the origin of the ice could be easily recognized by its structure, and that ice formed by snow water, even extremely rich in dissolved air, cannot be as porous as snow ice. He concluded that the ice at the Berezovka site was firn. Tolmachev also noted that it would be extremely interesting to study the structure of ground ice and suggested that new observations were necessary to solve all remaining problems, referring to the discussion between von Toll and von Bunge (Supplementary Quote S32). 


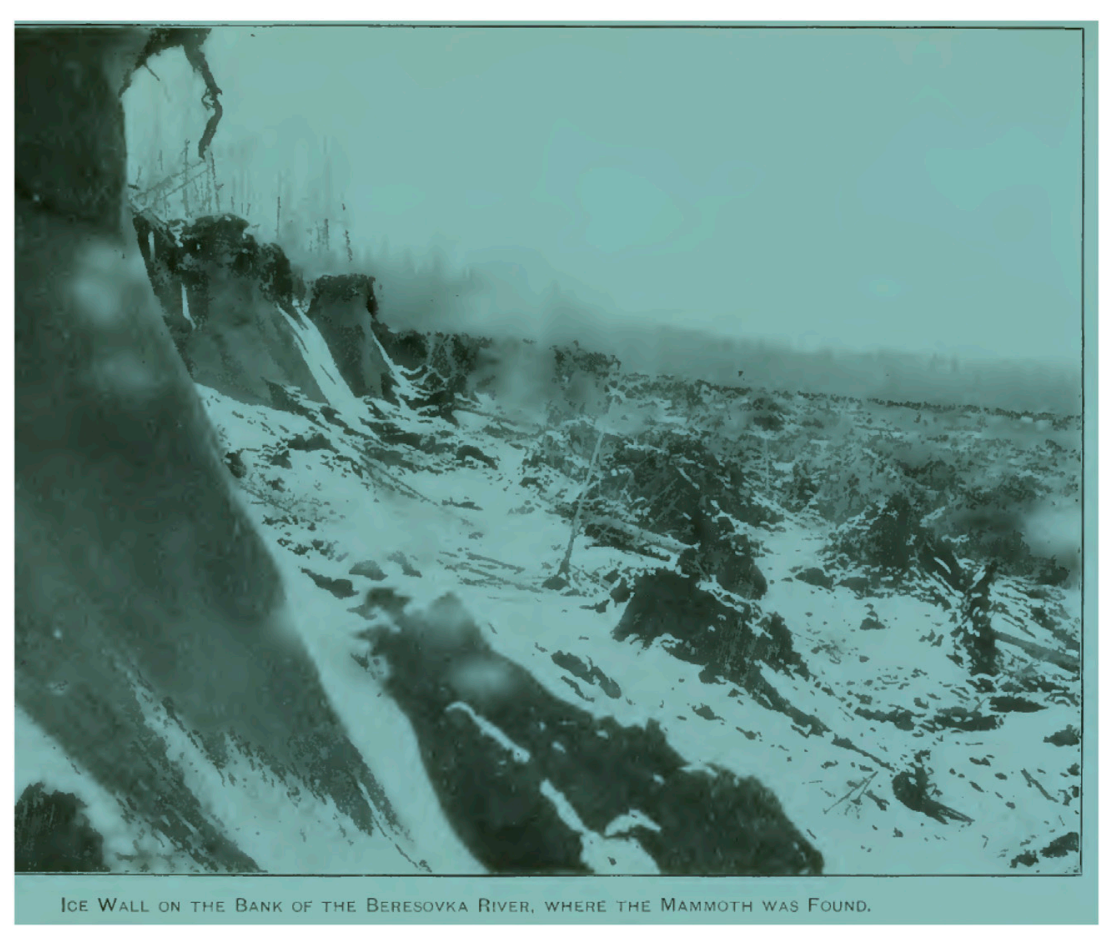

FIGURE 8 | Exposure of yedoma at the Berezovka River (Herz, 1904).

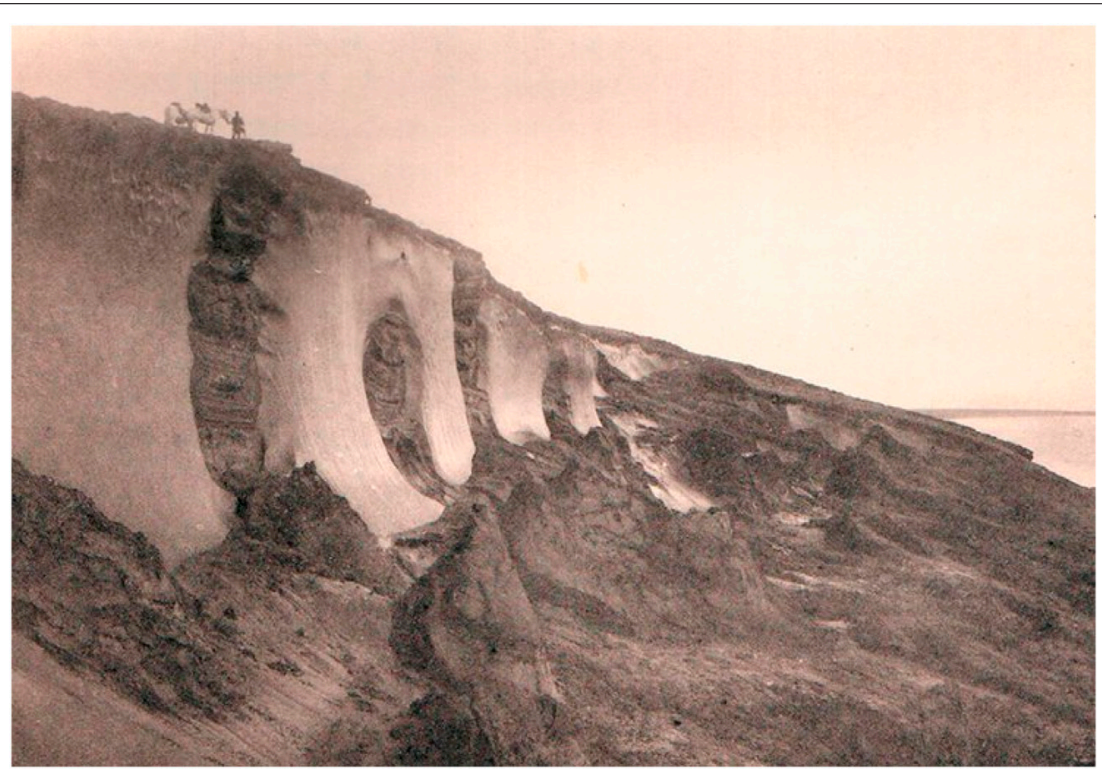

FIGURE 9 | Yedoma exposure at the mouth of the Bol'shaya (Rauchua) River (Tolmachev, 1911).

A few years later, Tolmachev (1906) visited the YeniseyKhatanga region and admitted that the wedge ice was much more common than he had previously thought (Supplementary Quote S33) During his expedition along the shore of the East Siberian Sea, Tolmachev (1911) found that Yedoma occurred widely west of Chaun Bay (Figure 9). At that time, he avoided the discussion of Yedoma genesis and described it as tundra sand-clay soil with inclusion of huge bodies of underground ice. The question of the ice's origin had been of interest to Tolmachev for several decades; he identified it as one of the most important problems of Arctic geology (Tolmachev, 1928; Tolmachoff, 1929) (Supplementary Quotes S34, 35). 
Vollosovich (1909, 1915), who participated in von Toll's expedition, shared von Toll's ideas on the origin of ice. At the Sanga-Yurakh mammoth site, Vollosovich (1909) described two ice horizons separated by a layer of soil and called this layer "the mammoth horizon." Later, Ermolaev (1932) did not find this horizon. In our interpretation, it seems that Vollosovich (1909) described soil accumulated on a thermal terrace as an original horizon. At Bol'shoy Lyakhovsky Island, Vollosovich (1915) also saw two layers of ice in the bluffs, separated by mudflow deposits and attributed them to two epochs of glaciation. In his opinion, the ice represented the remains of snowdrifts.

Sumgin (1927), the founder of the Russian (Soviet) Permafrost Institute, shared the opinion that ground ice of the New Siberian Islands, ice on the shore of the Arctic Ocean to the east of the mouth of the Lena River, and ice in the Lena-Aldan watershed was glacial ice. These ice masses, therefore, were interpreted as having been preserved in the ground from the glacial epochs to present. Sumgin was interested in Yedoma and mammoth fauna associated with it, which he considered as proof that permafrost was not a product of the contemporary climate but a very old formation.

Grigoriev (1927, 1930), a prominent Russian geographer and a founder of the Institute of Geography of the Russian Academy of Sciences, not only fully supported von Toll's opinion on ice formation, but also applied it to the formation of large bodies of massive ice with a thickness of up to 25-30 $\mathrm{m}$ in Central Yakutia (Supplementary Quote S36). According to Grigoriev (1927) descriptions, massive ice bodies in Central Yakutia consist of two types of ice-firn in the upper part and lake ice below it. Grigoriev (1927, 1930) described the formation of firn as followed: At the onset of a new period of glaciation and therefore a new climate, the rivers that had survived the new uplift of the country began to erode their channels intensively. This river erosion deepened, widened and created a new surface cut into previously deposited sediments. The rivers that had broken up and became separate lakes, underwent a different fate. In these lakes (due to the absence of flowing water), the freezing of water occurred deeper than in the active rivers. Thus, these lakes froze back to the bottom in most cases in winter (as is occurs in some undrained lakes of the area even today). Increased precipitation led to a greater accumulation of snow in the depressions. The snow covered the ice and prevented it from melting in the summer, as it was not able to melt completely under the climatic conditions of the time. Thus, the ice recrystallized into a granular structure, and lake basins were gradually filled with firn, which was deposited on top of lake ice. If at the beginning of this process there was still unfrozen water under the ice, it froze somewhat later, being exposed to the low temperature of the permafrost. In Grigoriev's opinion, the difference between these two types of ice was so obvious that they could not be missed in an exposure or a drilling core.

Ermolaev (1932) studied Yedoma on Bol'shoy Lyakhovsky Island and shared von Toll's opinion on ice genesis, but disagreed with Vollosovich on the existence of the two ice horizons. Ermolaev paid more attention than others to the deposits filling "cracks in ice." He found that soil was homogeneous with the size of most particles in the range $0.05-0.01 \mathrm{~mm}$. This silty soil was interbedded with thin layers of ice, which were curved up at contacts with massive ice. During a summer, these cracks were a drainage pathway for meltwater. Water running from higher elevations, as well as winds, deposited silt over the ice layer. Such a cycle repeated every year and produced a series of silt-ice layers. The volume of ice within the sediment filling these cracks was about $70 \%$. Peat that occurred in these cracks was also brought in by water. Ermolaev found that the structure of the ice was similar to ice from the Berezovka River exposure that was described earlier by Tolmachev (1903). Ermolaev (1932) described the soil wedges, or rather those spaces between the ice walls that were subsequently filled with soil, in relation to the genesis of the ice. Whatever their origin, he considered them a consequence of some coherent system of stresses existing within the whole mass of solid ice and that they could have been caused by a process that involved the entire ice mass. Ermolaev, a mechanical engineer by education, considered a few possible models of ice cracking and concluded that the ice was a glacier, and cracks in the ice were caused by ice folding. Based on his mechanical model, he estimated that the thickness of ice sufficient for such stresses should be 70-80 m. In light of modern knowledge of the origin of Yedoma, we can consider Ermolaev's evaluations as erroneous, and this example shows the importance of developing the correct conceptual models before quantitative modeling.

Vladimir A. Obruchev (1931), a patriarch of Siberian Geology, also supported von Toll's ideas. He believed that this fossil ice also had an extensive distribution along the coast of the Arctic Sea. He considered that most of it was formed during a glacial period and was represented by stagnant ice detached from glaciers during their retreat, with parts of it being remnants of stagnant firn fields (Supplementary Quote S37). The remnants of fauna and flora, found very often in wedge-shaped and pillar-like masses of layered sediment deposited among the ice bodies, supported his concept of ice that had formed during the last glaciation.

In 1940, the government of the Republic of Yakutia asked the Obruchev Permafrost Institute to investigate the distribution and properties of buried glacier ice in the vicinities of Abalakh Lake, Central Yakutia, for the purpose of extensive development of the area. Experienced permafrost scientists, such as N.A. Grave, A.I. Efimov, and P.A. Soloviev actively participated in this study and produced numerous reports and papers describing their investigations. According to Grave (1944), a buried firn field had occupied the vast area of the Lena-Aldan watershed; he identified specific locations of buried ice. He documented ice thicknesses of 25-30 m and estimated from the depth of alases (thermokarst basins) that it could reach up to $40 \mathrm{~m}$. Grave presented a preliminary map of buried ice in the region. Based on an example of the exposure of buried ice (Figure 10), Grave found great similarity of the structure and shape of buried ice of the Lena-Aldan watershed with the fossil firn field of the North Cape of Bykovsky Peninsula, from which he concluded that they were formed simultaneously. He considered as proven that the fossil ice was formed from accumulations of snow and firn. The ice structure, the absence of moraines, and presence of meadow soil under ice without any traces of ice scouring were to Grave evidence of such a genesis. He noticed, but did not clearly explain, the homogeneous nature of the ice and absence of infiltration ice 


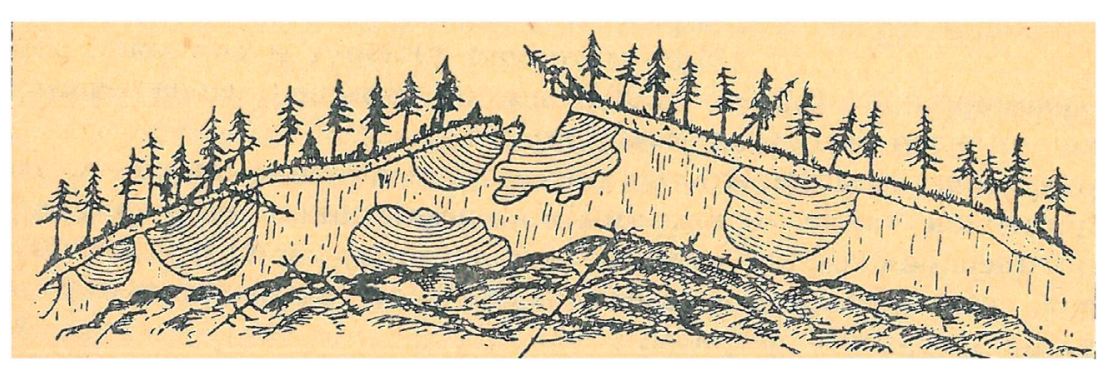

FIGURE 10 | Exposure of "fossil ice" with layered inclusions of soil at the left bank of the Aldan River (Grave, 1944).

in it. Studies driven by this approach regarding the genesis of ice were continued by the Permafrost Institute until 1950 (Shumskii, 1952).

Saks (1947) came to conclusion that the massive ice on the New Siberian Islands is not a thick continuous layer of firn but rather numerous separate snowfields. Gorodkov (1948), a leading Russian Arctic biologist, expressed his opinion on the nature of ice at Kotelny Island. He described the massive ice with inclusions of silt and small air bubbles, which was penetrated by thick wedges of a loess-like deposit and covered with a layer of loesslike silt about 40-60 cm thick. Gorodkov studied the properties of the ice and came to conclusion that it originated from firn. He also explained that soil wedges in ice formed as a result of silt accumulation in depressions that had developed from melting ice (Supplementary Quote S38).

Interesting, that Geikie (1894), the author of the monumental monograph on the Ice Age, compared ground ice formations of Northern Alaska with those of Siberia that had been previously described by von Toll and also came to conclusion that they are very similar and represent snowdrifts of a late glacial epoch (Supplementary Quotes S39, 40).

\section{YEDOMA STUDIES IN NORTH AMERICA AT THE FIRST HALF OF THE 20TH CENTURY}

In North America, ice- and organic-rich silt known to permafrost scientists as Yedoma was named 'muck' by gold miners in Canada and Alaska. Tyrrell $(1904,1917)$ studied "muck" deposits in the Klondike District, Yukon Territory, Canada. In some areas, he described muck strata up to $30 \mathrm{~m}$ thick that contained layers of clear ice. Tyrrell interpreted the ice as an underground icing formed by springs; the vertical veins or dikes of ice in his descriptions indicated positions of former water channels (Supplementary Quote S41).

Maddren (1905), who mapped known areas of Quaternary deposits with locations of Pleistocene mammals across Alaska, shared Russell's explanation of ice formation and was passionate about the idea of a lacustrine origin of ground ice (Supplementary Quote S42). Maddren was so confident with this idea of ice formation that he even modified Tolmachev's (1903) sketch of the bluff of the Berezovka River and added that the ice is underlined by silt of lacustrine genesis, which was not stated by Tolmachev. Tolmachev's statement was originally written as: "It can be ascertained, however, that the origin of such ice is easy to recognize by its structure. No matter how rich in air dissolved in snow water, it cannot make ice as porous as snow ice" (Tolmachev 1903, p. 133). However, Maddren's translation gave it the opposite meaning: "It may be remarked, the formation of the ice in such a way cannot be deduced from its structure." Maddren appears excessively critical of Tolmachev and overconfident in his own statements as for example, in one of his conclusions on Alaska he stated that there was no evidence that the climate of the Arctic had been colder in the Pleistocene than at present, and there were no ice-rich deposits of the Pleistocene age except glacial (Supplementary Quote S43).

A decade later, Leffingwell $(1915,1919)$ fully supported von Bunge's idea: "The writer leaves the origin of this ice an open question but holds the opinion that the most favorable line of inquiry will be along the lines suggested under the theory of ice wedges" (Leffingwell, 1919, p. 223). He even regretted that he did not know von Bunge's work when he began his studies of ice wedges in Alaska. Commenting on von Bunge's and von Toll's dispute, Leffingwell was surprised that von Bunge's theory did not get support in Russia. He saw some challenging questions in an application of the ice-wedge theory to Yedoma locations (during his work along the Beaufort Sea coast of Alaska, Leffingwell did not observe any Yedoma exposures). Nevertheless, Leffingwell presumed that symmetrically distributed inclusions of earth in Yedoma cliffs were closely related to symmetrically arranged frost cracks; he also figured out that the surface could grow upward because of the pressure that polygonal blocks had experienced from the growing ice wedges (Supplementary Quote S44). Earlier in his famous paper on the formation of wedge ice, Leffingwell (1915) was close to our understanding of syngenetic formation of ice wedges: "The usual covering for the ice is muck capped by turf, or peat capped by growing sphagnum (?) moss. As the thickness of this mantle increases by surface growth, the limit of the summer's thawing should rise, thus allowing a constant upward extension of the surface of the ice wedge at the locus of growth" (Leffingwell, 1915, p. 648). Thus, Leffingwell described two cases of "apparent upward growth of the surface." Leffingwell (1915) also commented on Yedoma in Alaska, suggesting that much of the ground ice at the famous bluffs at Eschscholtz Bay could be wedge ice (Supplementary Quote S45).

Between 1900 and 1920, ice-rich silt that we interpret as Yedoma was also observed in various parts of Alaska 
(Figure 1B) by Gilmore (1908), Quackenbush (1909), Prindle et al. (1913), Smith (1993), and Harrington (1918).

Wilkerson (1932), a geology professor at the Alaska Agriculture College and School of Mines (now the University of Alaska Fairbanks), provided detailed descriptions of both the fine-grained, organic-rich silt (muck) and ground ice. He believed that the gold-bearing gravels and overburden soil were frozen soon after deposition, and that the upper portions were thawed each summer with the depth of thawing never quite equaling the depth of freezing. Thus, the thickness of the frozen materials was the result of numerous additions of materials that were frozen shortly after deposition. He argued that the 30-40 feet thickness of the deposits indicated that freezing could not have occurred after the whole thickness of the deposits had been formed. Wilkerson concluded that ice bodies were buried icings (called "glaciers" by the miners and some geologists) that had formed along hillsides by the groundwater seepages. He presumed that the ice was preserved by a protective mantle of muck, gravel, sand, and peat.

To Porsild (1938), the process of ice formation in Yedoma was identical to the formation of an open system pingo as we understand it now. Based on his studies of pingo formation in Canada and Alaska, he presumed that a similar process could lead to formation of sheets of solid ice in the Kotzebue Sound region and on the Seward Peninsula, as well as in other unglaciated parts of Alaska (Supplementary Quote S46).

Tuck (1940), a geologist with the USGS, observed Yedoma ("muck") exposures at gold mining sites near Fairbanks, Alaska. He described the fine-grained composition of mineral soil, the abundance of organic material, high water content, and vertebrate remains. He identified three types of ground ice that occurred in: 1) soil pore space and comprised $50 \%$ of the total mass; 2 ) sills from a few inches to 10 feet thick; and 3 ) dikes (wedges) formed in tension cracks filled with water. Figures in Tuck's paper show that sills and dikes were just different projections of ice wedges. He hypothesized that sills formed at the same time as the muck and, in his opinion, the muck was of aeolian origin and its freezing occurred almost simultaneously with deposition (Supplementary Quote S47).

\section{REACHING MODERN TIMES: TABER'S "ORIGIN OF GROUND ICE"}

Taber (1943), who spent the summer of 1935 studying permafrost in Alaska, published the first comprehensive monograph on permafrost in Alaska. The content of this important paper, the history of its writing and publication, acceptance by peers, and its legacy were discussed in the recent review by Nelson and French (2021). Here we discuss mainly one chapter of this monograph-"Origin of ground ice"-in which Taber explained his vision of the origin of Yedoma.

In the previous decades before his paradigm-changing monograph, Taber performed outstanding laboratory experiments and developed fundamentals of still valid views on the impact of soil freezing on properties of frozen ground and the associated frost heave (Taber, 1930). There is no doubt that Taber's contribution to permafrost science and engineering was enormous. Taber visited Alaska during the time of extensive active gold mining and observed Yedoma exposures in open pits in both the Fairbanks area and the Seward Peninsula. Taber understood the existence of epigenetic and syngenetic permafrost and indicated that, in an attempt to solve the problems of permafrost formation and the development of ground ice, one should consider four scenarios (Taber, 1943, p. 1504):

1) The deposits were formed during a warmer climate and subsequently frozen as a result of climatic conditions now prevailing;

2) deposition and freezing occurred simultaneously under climatic conditions now prevailing;

3) the deposits were formed during a warmer climate and subsequently froze as a result of a change to a colder Pleistocene climate; and

4) deposition and freezing took place simultaneously during a Pleistocene climate that is colder than what is now prevailing."

In terms of the origin of Yedoma, scenarios 1) and 2) contradict the presence of well-preserved remnants of mammoths and other prehistoric animals whose presence in the deposits is only possible in a frozen state and, therefore, only permafrost formation during the Pleistocene should be considered. Unfortunately, Taber did not discuss details of syngenetic permafrost formation (scenario 4). He applied his understanding of the formation of frozen soil from his laboratory experiments to natural processes and features that were completely new to him.

Taber's experiments reproduced epigenetic permafrost formation in both closed and open systems. The experiments did not include processes representative of simultaneous soil deposition and freezing, the existence of a periodically thawed soil at the surface, and they excluded the possibility of a surface water supply to a soil undergoing freezing. Taber concluded that the Yedoma sediment accumulated before its freezing that occurred downward from the surface, and the ice-rich soil and ice wedges were formed as a result of epigenetic freezing of soil in an open system with water migrating from underlying gravel where it was subjected to hydrostatic pressure.

During his field studies, Taber noticed extremely high water content of soil, yet he did not comment on it. We now know that it is impossible to achieve such high water contents from experiments with epigenetic soil freezing. Taber (1943, page 1526) dismissed all existing hypotheses of ice formation in Yedoma and found that "none of the older hypotheses is competent from the standpoint of physics." Building on his numerous laboratory experiments and interpretation of field observations, Taber outlined a new hypothesis of the origin of ground ice in Yedoma. Its main idea was that ice lenses formed a layered cryostructure and that ice lenses and ice wedges were developed in one process of ice segregation.

Taber separated the accumulation of silt and its freezing in time and stated that "freezing to a depth of several hundred feet, with the formation of great masses of ground ice, required a very long time" (Taber 1943, p. 1533-1534). This "very long time" is 


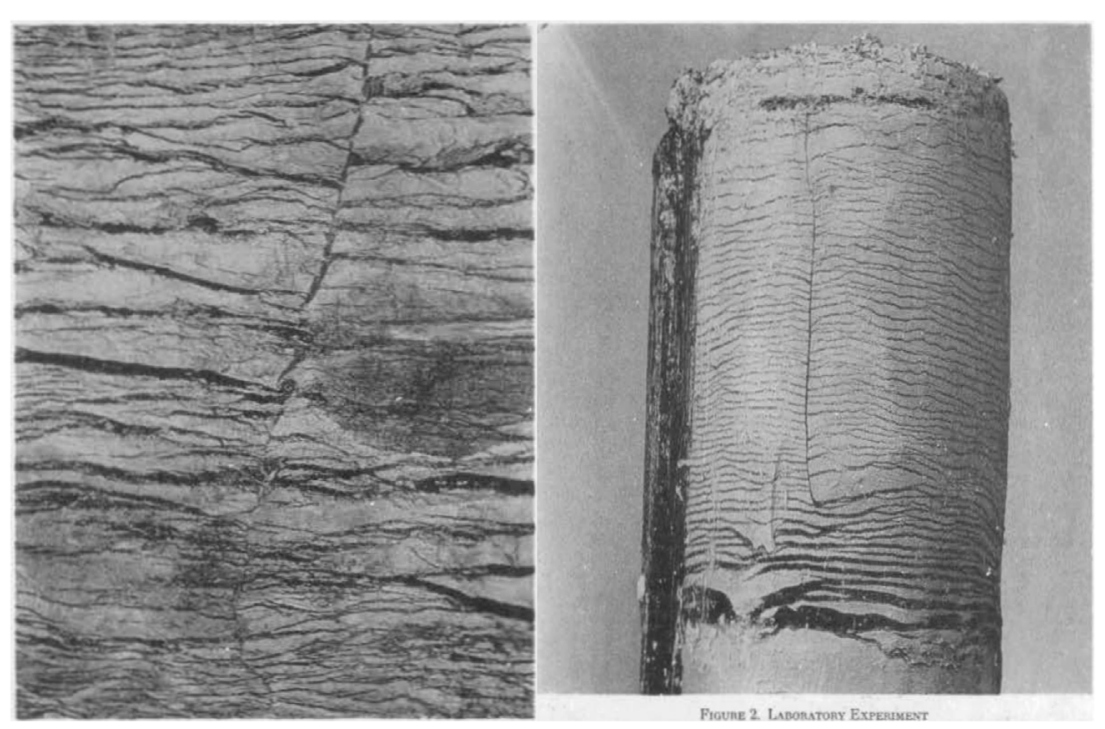

FIGURE 11 | Cryostructures of frozen soils (Taber, 1943). Left-from the exposure in an underground cold-storage excavation at Deering, Alaska; Right-from a laboratory experiment.

critical to Taber's new hypothesis. He believed that the smallscale polygonal structure formed in his experiments, continuing for days, could reach the size of ice-wedge polygons if freezing continued for thousands of years.

To prove his idea, Taber described an exposure in an underground cold-storage excavation at Deering (Alaska), which he found to be among the best and most remarkable exposures that he had ever examined. He compared a photograph of this exposure with a photograph taken from his experiments, and they show a perfect match (Figure 11). Unfortunately for Taber, the cryostructure of the exposed soil was not typical of Yedoma based on our present-day knowledge.

In the 1940-1960s, soils that we now identify as Yedoma, were described in various areas of Alaska including Seward Peninsula, the Yukon Flats, and the Yukon-Tanana uplands, and most researchers supported an aeolian genesis of soil (Black, 1951; Péwé, 1955, 1975; Williams, 1962; Hopkins, 1963; Sellmann, 1967).

\section{STUDIES IN GERMANY AND THE FURTHER DEVELOPMENT OF THE ICE-WEDGE THEORY IN RUSSIA AND NORTH AMERICA}

Sörgel (1936), studying ice-wedge casts in Thuringia, Germany, stated that "what diluvial ice wedges or wedge crevasses show in shape differences compared to Alaskan ice wedges is explained within the same genetic principle by the special conditions in the periglacial area at the time of diluvial ice wedge formation. These shape differences also confirm the ice wedge nature of the diluvial wedge crevasses." He came to an idea that the accumulation of sediment and formation of wedge ice can occur simultaneously. Earlier, Leffingwell (1915) mentioned such a process in relation to accumulation of peat. Sörgel's paper could have been a very important step in the explanation of Yedoma genesis, even if it had not directly dealt with Yedoma deposits. Unfortunately, this did not happen, and his paper was ignored. Scientists from the Obruchev Permafrost Institute, working in Central Yakutia, were mainly led by Grigoriev's ideas, Arctic geologists in Russia agreed with von Toll, and Taber worked hard to explain wedge ice as segregated.

Another important paper, which could have helped to explain the formation of massive ice in Yedoma, was written by Gallwitz (1949). Based on ice-wedge casts studies in Germany, he distinguished two types of ice wedges (epigenetic and syngenetic) and tried to derive information about permafrost conditions from the ice-wedge shapes. The importance of the Gallwitz' work for understanding of simultaneous formation of ice wedges and accumulation of sediment was stressed by Shumskii (1960).

Alexander I. Popov (1952), a scientist of the Obruchev Permafrost Institute, was the first to propose a hypothesis that led to the solution of the Yedoma formation problem. Working on the Taymyr Peninsula in 1949, Popov described ice wedges in a floodplain deposit and in the first terrace of the Mamontova River. He concluded that the formation of ice wedges takes place on a floodplain and the growth of ice occurs upwards and sideways accompanied by an increase in deposited floodplain sediments. Popov (1952, p. 17) concluded: "If ice growth is related to the mode of sediment accumulation, then we should also consider changes in this environment, i.e., epeirogeny dips and rises of alluvial plains. The correlation between the rate of sinking or uplift of an alluvial plain, the amount of water in the flood, the thickness of the annually accumulated sediment, and its composition determines the conditions of ice accumulation. Depending on the relation of these factors, either thick or thin ice is likely to accumulate, as well as the expansion of wedges sidewise." 


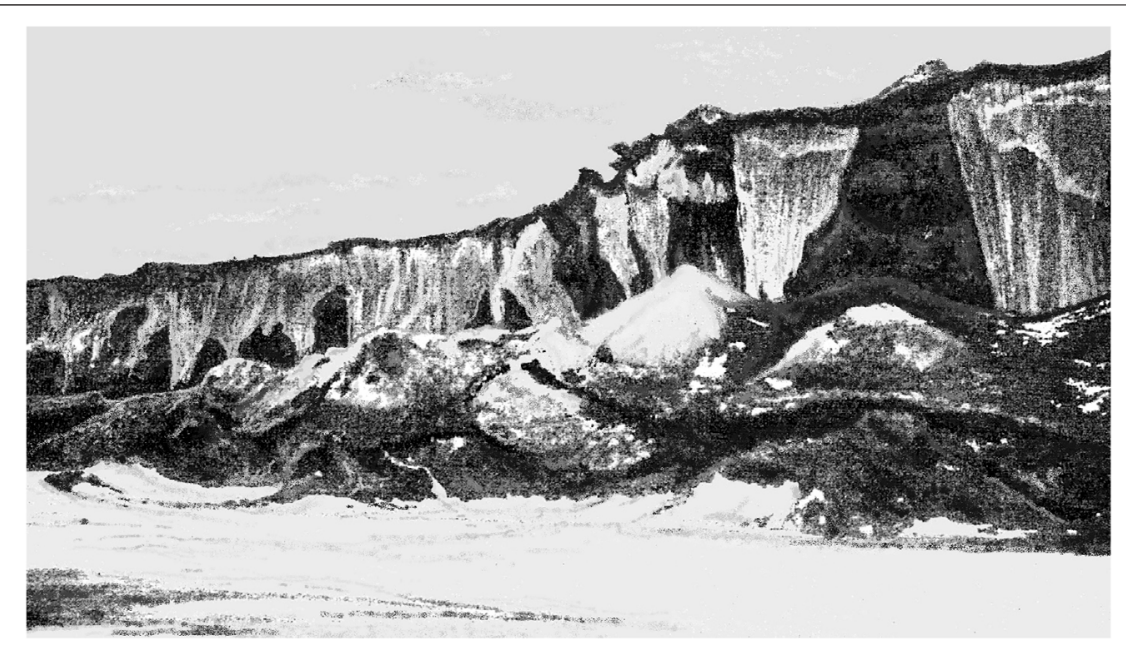

FIGURE 12 | Photo of Yedoma by Vollosovich (1909), which was used as an illustration by Popov (1952).

Popov also observed foliations in the ice that were similar to the foliations on photographs taken by von Bunge and published by von Toll (1895). Before his first publication on the origin Yedoma, Popov had not personally seen Yedoma exposures and the photograph (Figure 12) in his publication was copied from a work by Vollosovich (1909). Popov extrapolated the processes of syngenetic permafrost formation involving the simultaneous growth of ice wedges that he had observed on a floodplain to the larger scale of Yedoma formation.

In this unifying connection, Popov was primary responsible for resolving the mystery of Yedoma genesis in spite of limiting Yedoma formation to floodplains of Arctic rivers. Popov's idea was proven a few years later by researchers of the Obruchev Permafrost Institute in Northern and Central Yakutia (Shumskii, 1952; Katasonov, 1954; Vtyurin, 1955; Korkina, 1959). (Shumskii (1952), p. 143) wrote about difficulties they encountered during these studies: "The mystery of the nature of the ice was due to its shape and the lack of anything resembling it among modern formations and the lack of direct observation of its formation. The relationship between fossil ice and soil is complicated and it requires hard work to clarify it. Exposures observed in natural environments allowed different interpretations."

Under the impact of Popov's work, Yedoma studies by the Obruchev Permafrost Institute in Central and Northern Yakutia were subsequently based on understanding the syngenetic nature of Yedoma involving sedimentation and ice-wedge formation occurring simultaneously. Among numerous results of these productive studies, there is a clarification of the Yedoma appearance in different projections by Shumskii (1959) which explains a puzzling and often confusing appearance of soil and massive ice in Yedoma exposures (Figure 13).

Russian Arctic geologists have had reservations about the explanation for Yedoma formation by permafrost scientists. Gusev (1954, 1958) still considered underground ice of Yedoma as buried firn or buried icings. Ermolaev visited Oyagossky Yar in 1968 and did not recognize ice wedges there (Ermolaev and Dibner, 2009).
Another important problem of Yedoma studies is the origin of sediments that host large syngenetic ice wedges. According to Popov (1967), the most favorable conditions for the syngenetic growth of ice wedges take place on floodplains, deltas, and in other similar depositional environments associated with tectonic lowering of the terrain, and in climate with low snow precipitation. He believed that Yedoma had been formed in such an environment. This was a guideline for numerous scientists in Russia for many decades even though some of them noticed the absence of the channel facies beneath a "floodplain deposit" (e.g., Romanovskii, 1958).

Shumskii et al. (1955) did not limit Yedoma formation to the floodplain environment. They stated (pp. 15-16): "If, simultaneously with the formation of ice wedges, new sediments accumulate on the soil surface-the growth of peatlands in swampy lowlands, alluvium deposits in river floodplains, slopewash at the foot of slopes, etc.-the upper boundary of continuous frozen strata gradually rises as the ground surface rises, and with it, ice wedges grow. Under such conditions, the ice wedges grow not only in width, but also upward, penetrating the accumulating strata of frozen deposits to their full thickness." This important insight had been unnoticed by permafrost researchers studying Yedoma, possibly because the publication addressed geological engineers specifically and not permafrost scientists, and as a result, the alluvial theory had prevailed for years.

An important deviation from the alluvial theory of Yedoma formation was work done by Gravis (1969). His detailed studies of frozen soil in numerous deep boreholes and pits in the foothills of the Kular Range in Northern Yakutia showed that an accumulation of Yedoma with tall ice wedges and typical cryostructures resulted from the accumulation of slope deposits.

Earlier (Schirrmeister et al., 2013) we distinguished between the dominant aeolian Yedoma genesis in Alaska/Canada and varying formation conditions in Siberia. In Russia, the aeolian theory was not popular. While Gravis' work was agreeably 


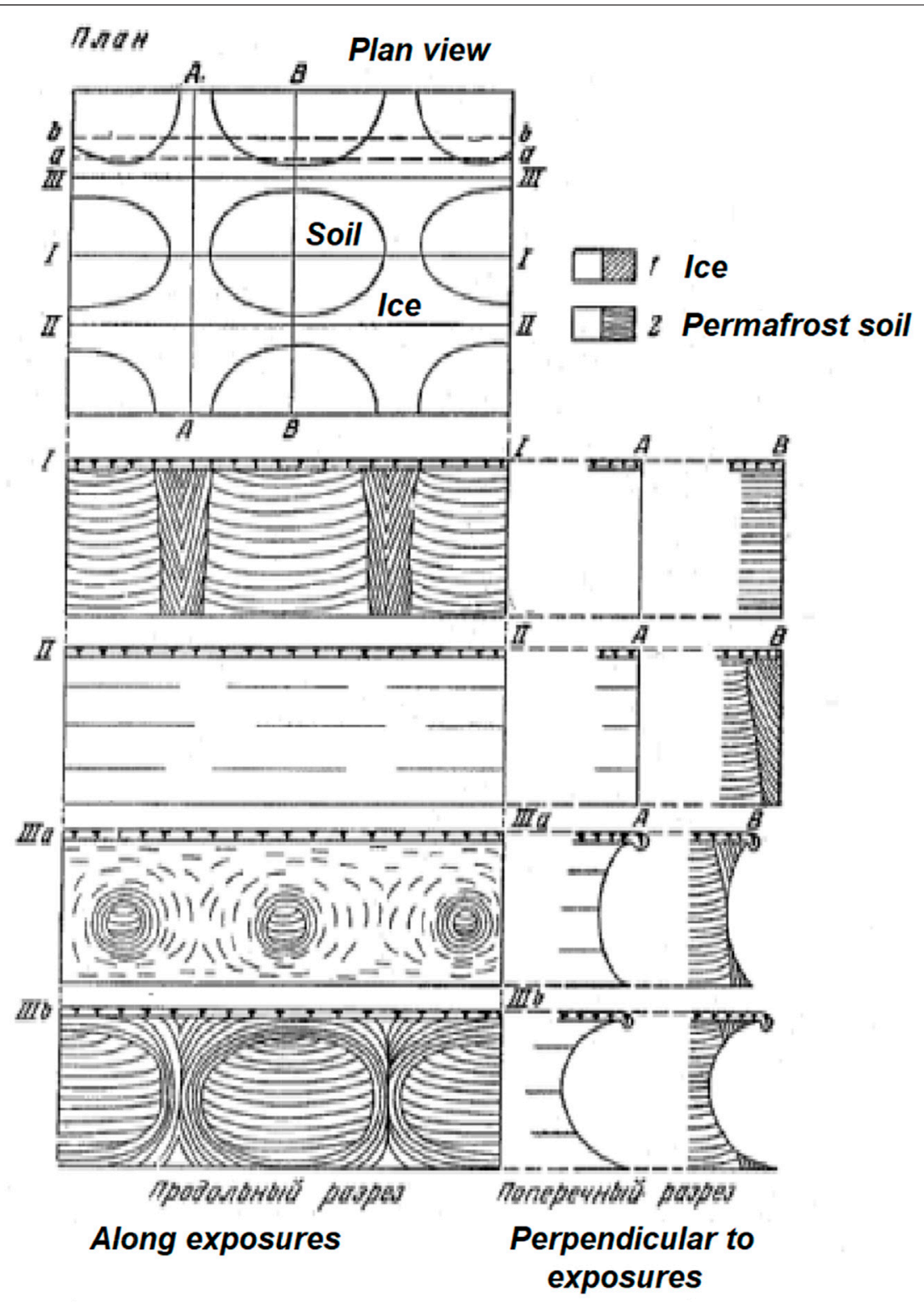

Фиг. 74. Схема строени запежи жильмих льдов н тнпниных форм нихода льдов в обнажениях.

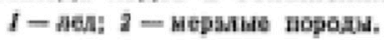

FIGURE 13 | Appearance of ice wedges and adjacent soil in exposures with different projections (Shumskii, 1959). Top image-plan view of the ice-wedge network; I, II, III a, III b-projections along exposures (visual appearance in the exposures); A, B-projections perpendicular to exposures (cross sections).

accepted by many permafrost scientists in Russia, the hypothesis of an aeolian genesis of Yedoma as proposed by Tomirdiaro (1978) met fierce opposition. His appeal to a similar opinion held by Péwé (1955) on the origin of Yedoma in Alaska did not help.

Konishchev (1981) supported the polygenetic origin of Yedoma and presumed that it could form in fluvial, slope, and lacustrine deposits. Zhestkova et al. $(1982,1986)$ agreed with the polygenetic origin too: they considered Yedoma as a climatic phenomenon because the mode of sediment accumulation did not restrict the formation of Yedoma. They also pointed out the importance of pedological processes and vegetation in the formation of properties of Yedoma and suggested considering Yedoma as a gigantic polypedon.

Extensive Yedoma studies during and after the 1950s had an enormous impact on the permafrost science. We agree with Konishchev (1981), who believed that cryolithology as part of permafrost science was triggered by the study of Yedoma genesis. He divided the study of massive ground ice into two 
stages. The first stage during the 19th and the first half of the 20 th centuries involved the confrontation between supporters of a glacial origin and the proponents of an ice-wedge origin for the development of massive ground ice. A way out of this impasse was the concept of syngenetic growth of polygonal wedge ice and the simultaneous accumulation of host sediments as proposed by Popov, thus opening the door to the second (modern) stage of ground-ice studies.

After the long-held theory of a glacial origin of Yedoma there is tendency now to explain any large body of underground ice as wedge, segregated, or intrusive ice (Dubikov and Koreisha, 1964; Gasanov, 1969; Baulin and Dubikov, 1970; Mackay, 1971). Robust evidence of buried glacier ice has been found in Canada and Russia (e.g., Solomatin, 1986; Kokelj et al., 2017) but, ironically, it is currently difficult to convince the scientific community that buried glacier ice may exist in lowland areas (e.g., Sheinkman, 2017; Vasil'chuk, 2012). Recent findings (Anisimov et al., 2006; Basilyan et al., 2008) showed that buried glacier ice occurs in some parts of the New Siberian Islands, and sites of occurrence, properties and appearance of this ice are different from those that had been described in these areas by von Toll and von Bunge.

The origin of Yedoma is now considered a solved problem. Although discussions on the mode of sediment accumulation at specific Yedoma sites remain open, permafrost scientists agreed that Yedoma is late-Pleistocene syngenetic permafrost penetrated by ice wedges. This common understanding has helped to concentrate the attention of scientists on Yedoma as an outstanding and maybe the best source of information regarding the environment of the late Pleistocene. The number of Yedoma studies has been growing, and Yedoma has become one of the most intensive areas of permafrost research. The most recent synthesis article in English was published in the Encyclopedia of Quaternary Science (Schirrmeister et al., 2013).

\section{CONCLUSION}

In the beginning of the 19th century, the scientific world was introduced to an extraordinary geologic feature-Yedoma permafrost. It appeared as a strange combination of big masses of underground ice and deposits containing remnants of extinct Pleistocene animals, including mammoths. Since then, numerous geologists, geographers, and biologists proposed many hypotheses to explain the origin of this feature. They focused their attention predominantly on the ice and didn't consider the soil as an important component of Yedoma. Most of scientists at the time ignored soil completely, while others considered it as later inclusions within the ice. The two-dimensional appearance of Yedoma in exposures was often confusing. Explanations of ice genesis by geologists based on their previous knowledge have been unsuccessful. Features proposed in some hypotheses, like buried lake ice, have never been observed. The obsession with the origin of massive ice in Yedoma blocked scientific studies for many years.
The erroneous opinions of prominent and influential scientists prevailed over the currently accepted idea, proposed by Dr. Alexander von Bunge, and delayed attaining the solution of Yedoma origin for over 50 years. History shows that a mere hypothesis without ways for verification has a very low possibility to be fruitful. Chamberlin (1897) warned of the danger of premature theories: "The habit of precipitate explanation leads rapidly on to the development of tentative theories. The explanation offered for a given phenomenon is naturally, under the impulse of self-consistency, offered for like phenomena as they present themselves, and there is soon developed a general theory explanatory of a large class of phenomena similar to the original one. This general theory may not be supported by any further considerations than those which were involved in the first hasty inspection. For a time, it is likely to be held in a tentative way with a measure of candor. With this tentative spirit and measurable candor, the mind satisfies but the thoroughness, the completeness, the allsidedness, the impartiality, of the investigation. It is in the tentative stage that the affectations enter with their blinding influence."

The search for the origin of Yedoma shows that when confronting new and extraordinary phenomena, both prominent scientists and young researchers have an equal chance to propose a valuable idea. It is interesting to note that in this controversy two medical doctors-Figurin and von Bunge-were much closer to deciphering the origin of Yedoma than many prominent geologists and geographers of their time. It seems that for a completely new problem, previous experience is not always an advantage but can be a burden that closes the mind to new ideas. As Kuhn (1970) noticed, “a new theory, however special its range of application, is seldom or never just an increment to what is already known. Its assimilation requires the reconstruction of prior theory and the re-evaluation of prior fact, an intrinsically revolutionary process that is seldom completed by a single man and never overnight."

After the mystery of Yedoma origin was generally solved as being syngenetic permafrost penetrated by ice wedges formed during the late Pleistocene, numerous international and interdisciplinary studies have been conducted in Russia, Alaska, and Canada. They have shown that during its formation Yedoma sequestered significant amounts of organic carbon and preserved a treasure of information on the environment of the late Pleistocene including its climate, vegetation, wildlife, and an extensive accumulation of syngenetic permafrost.

\section{AUTHOR CONTRIBUTIONS}

YS designed this study and drafted the first version of the manuscript. TJ compiled a map of Yedoma locations mentioned in the manuscript. YS, MK, and AV reviewed the Russian language references, LS and JS reviewed the German language references, and MWJ reviewed the French language references. YS, DF, MK, TJ, and MWJ reviewed the English 
language references. All co-authors contributed to the manuscript writing and editing process.

\section{FUNDING}

This study was supported by the National Science Foundation (NSF) grants OPP-1820883, OPP-1806213, and NNA-1928237. AV was supported by the Russian State Research Program No. 121041600043-4. This review was part of the Action Group "The Yedoma Region: A Synthesis of Circum-Arctic Distribution and Thickness," funded by the International Permafrost Association (IPA) to JS.

\section{REFERENCES}

Adams, M. F. (1807). Relation d'un voyage à la mer glaciale et decouverte des restes d'un mamouth. St. Petersbourg. Journal du Nord XXXII, 633-650 (In French).

Adams, M. F. (1808). Some Accounts of a Journey to the Frozen Sea and the Discovery of the Remains of a mammoth. Philadel. Med. Phys. J. Part 13 , 120-137.

Anisimov, M. A., Tumskoy, V. E., and Ivanova, V. V. (2006). Tabular Massive Ice of New Siberian Islands as a Relic of Ancient Glaciation. Mater. glaciological Stud. 101, 143-145. (in Russian).

Basilyan, A. E., Nikolskiy, P. A., and Anisimov, M. A. (2008). Pleistocene Glaciation of New Siberian Islands - No More Doubt. News Int. Polar Year 2007/2008 \#12, 7-9. (in Russian).

Baulin, V. V., and Dubikov, G. I. (1970). Tabular Bodies of Massive Ice. Proc. PNIIIS 2, 175-1993. (In Russian).

Beechey, F. W. (1831). Narrative of a Voyage to the Pacific and Beering's Strait, Vols. 1 and II. London: Henry Colburn and Richard Bentley.

Birkengof, A. L. (1933). "Observations on forest and Permafrost," in Proceedings of Commission on Permafrost Studies. Editor V. A. Obruchev (Leningrad: USSR Academy of Sciences), Vol. 3, 41-58. (In Russian).

Black, R. F. (1951). Eolian Deposits of Alaska. Arctic 4, 89-111. doi:10.14430/ $\operatorname{arctic} 3938$

Cantwell, J. C. (1887). "A Narrative Account of the Exploration of the Kowak River, Alaska, under the Direction of Capt. Michael A. Healy, Commanding U.S. Revenue Steamer Corwin," in Report of the Cruise of the Revenue Marine Steamer Corwin in the Arctic Ocean in the Year 1885. Editor M. A. Healy (Washington, D.C: Government Printing Office), 21-52.

Cantwell, J. C. (1896). "Ice-cliffs on the Kowak River," in The National Geographic Magazine (Washington, D.C: The National Geographic Society), Vol. VII (10), 345-346.

Chamberlin, T. C. (1897). Studies for Students: The Method of Multiple Working Hypotheses. J. Geology. 5, 837-848. doi:10.1086/607980

Choris, L. (1822). Voyage pittoresque autour du monde. Paris: Impr. de Firmin Didot. (In French).

Dall, W. H. (1881). Notes on Alaska and the Vicinity of Bering Strait (Extract from a report to C.P. Patterson, Supt. Coast and Geodetic Survey). Am. J. Sci. XXI, 104-111. doi:10.2475/ajs.s3-21.122.104

Dall, W. H., and Harris, G. D. (1892). Correlations Papers - Neocene. Bulletin of the United States Geological Survey. Washington D.C.: Government Printing Office.

Dawson, G. M. (1894). Notes on the Occurrences of mammoth-remains in the Yukon District of Canada and in Alaska. Q. J. Geol. Soc. 50 (1), 1-9. doi:10.1144/ gsl.jgs.1894.050.01-04.03

Dubikov, G. I., and Koreisha, M. M. (1964). Fossil Intrusive Ice on Yamal Peninsula. Trans. USSR Acad. Sci. Geography 5, 55-65. (In Russian).

Ermolaev, A. M., and Dibner, V. D. (2009). Arctic Scientist, Gulag Survivor. The Biography of M.M. Ermolaev. Calgary, Alberta: University of Calgary Press.

Ermolaev, M. M. (1932). Description of Geology and Geomorphology of Bol'shoy Lykhovsky Island. Proc. SOPS USSR Acad. Sci. 7, 147-226. (In Russian).

\section{ACKNOWLEDGMENTS}

We acknowledge the editor Duane Froese and reviewers Mary Edwards, Fritz Nelson, and Vladimir Tumskoy for their constructive critique and useful suggestions. We also greatly appreciate Joan Welc-LePain's help in editing the manuscript.

\section{SUPPLEMENTARY MATERIAL}

The Supplementary Material for this article can be found online at: https://www.frontiersin.org/articles/10.3389/feart.2021.757891/ full\#supplementary-material

Figurin, A. E. (1823). "Notes by Medical Doctor Figurin on Natural History Observed in Ust-Yansk and its Vicinities," in Siberian Proceedings. Editor G. Spasskiy, 4, 185-248. (In Russian).

Gallwitz, H. (1949). Eiskeile und glaziale Sedimentation (Ice Wedges and Glacial Sedimentation). Geologica 2, 5-26. (in German).

Gasanov, Sh. Sh. (1969). Structure and History of Formation of Permafrost of East Chukotka. Moscow: Nauka. (In Russian).

Geikie, J. (1894). The Great Ice Age and its Relation to the Antiquity of Man. Third edition. London: Edward Stanford.

Gilmore, C. W. (1908). Smithsonian Exploration in Alaska in 1907 in Search of Pleistocene Fossil Vertebrates. Smithsonian Miscellaneous Collection. Part of volume LI, No 1807.

Gorodkov, B. N. (1948). Pleistocene Glacial Landscapes in Northern Asia. Proc. Acad. Sci. USSR LXI (3), 513-516. (In Russian).

Grave, N. A. (1944). Fossil Ice of the Watershed of the Lena and Aldan Rivers. Proc. Obruchev Permafrost Inst. 4, 10-32. (In Russian).

Gravis, G. F. (1969). Slope Deposits in Yakutia. Moscow: Nauka. (In Russian).

Grigoriev, A. A. (1927). "Geomorphology of Yakutia," in Commission on Studies of Yakut Republic (Leningrad: Academy of Sciences), Vol. 32, 39-89. (In Russian).

Grigoriev, A. A. (1930). Permafrost and Ancient Glaciation. Proc. SOPS USSR Acad. Sci. 80, 43-104. (In Russian).

Gusev, A. I. (1954). On a Genesis of Fossil Ice. Proc. Inst. Arctic Geology. 43 (Issue 3), 173-183. (In Russian).

Gusev, A. I. (1958). On Stratigraphy of Quaternary Deposits of Western Part of Coastal Plain. Proc. Inst. Arctic Geology. 80 (Issue 5), 79-86. (In Russian).

Harrington, G. L. (1918). The Anvik-Andreafski Region Alaska. United States Geol. Surv. Bull., 525.

Herz, O. F. (1904). Frozen Mammoth in Siberia: Ann. Rep (Washington: Smithsonian Institution), 611-625.

Hooper, C. L. (1884). Report of the Cruise of the U.S. Revenue Steamer Thomas Corvin, in the Arctic Ocean. Washington D.C.: Government Printing Office, 1881.

Hopkins, D. M. (1963). Geology of the Imuruk Lake Area, Seward Peninsula, Alaska. Washington, D.C.: U.S. Government Printing Office. U.S. Geological Survey Bulletin 1141-c.

Katasonov, E. M. (1954). Lithology of Frozen Quaternary Deposits (Cryolithology) of Yana Coastal Plain (Moscow: The Obruchev Permafrost Institute). Ph.D. Thesis. (In Russian).

Kokelj, S. V., Lantz, T. C., Tunnicliffe, J., Segal, R., and Lacelle, D. (2017). Climatedriven Thaw of Permafrost Preserved Glacial Landscapes, Northwestern Canada. Geology 45 (4), 371-374. doi:10.1130/G38626.1

Kolchak, A. V. (1906). The Last Expedition to Bennett Island Sent by Academy of Sciences in Search for Baron Toll. News of Russian Imperial Geographic Society. Vol. XLII issues II-III: 487-519. St. Petersburg (In Russian)

Konishchev, V. N. (1981). Formation of Dispersed Rocks in Cryo-Lithosphere. Novosibirsk: Nauka. (In Russian).

Korkina, R. I. (1959). On Genesis of Fossil Ice of Central Yakutia. Regional Permafrost-Geophysical Investigations. Proc. Obruchev Permafrost Inst. 15, 113-131. (in Russian). 
Kuhn, T. S. (1970). "The Structure of Scientific Revolutions," in International Encyclopedia of Unified Science (Chicago: The University of Chicago Press), Vol. II.

Leffingwell, E. K. (1915). Ground-ice Wedges the Dominant Form of Ground-Ice on the north Coast of Alaska. J. Geology. 23 (No 7), 635-654. doi:10.1086/ 622281

Leffingwell, E. K. (1919). The Canning River Region Northern Alaska. Washington D.C: United States Geological Survey, Professional Paper 109.

Lopatin, I. A. (1876). Some Information on Ice Strata in Eastern Siberia. Appendix 1 Proc. Acad. Sci. XXIX, 3-32. (In Russian).

Mackay, J. R. (1971). The Origin of Massive Beds in Permafrost, Western Arctic Coast, Canada. Can. J. Sci. 8 (No 4), 397-4244. doi:10.1139/e71-043

Maddren, A. G. (1905). Smithsonian Exploration in Alaska in 1904, in Search of Mammoth and Another Fossil Remains. Smithsonian miscellaneous collections. Washington: The Smithsonian Institution, Vol. XLIX.

Mendenhall, W. C. (1902). Reconnaissance from Fort Hamilton to Kotzebue Sound, Alaska. Washington: Government Printing Office. United States Geological Survey Professional paper no. 10.

Muir, J. (1917). The Cruise of the Corwin: Journal of the Arctic Expedition of 1881 in Search of De Long and the Jeannette. Cambridge: The Riverside Press.

Murzaev, E. M. (1984). Dictionary of Folk Geographical Terms. Moscow: Mysl. (In Russian).

Nelson, F. E., and French, H. M. (2021). Stephen Taber and the Development of North American Cryostratigraphy and Periglacial Geomorphology. Permafrost and Periglac Process 32, 213-230. doi:10.1002/ppp.2096

Obruchev, V. A. (1892). Soil Ice and Conditions of Conservation of Post-Tertiary Carcasses in Northern Siberia of Baron Toll. Izvestia Russkogo Geograficheskogo obshestva 23 (2), 1-14. (In Russian).

Obruchev, V. A. (1931). Signs of the Ice Age in North and Central Asia. Bull. Comm. Quat. Stud. Issue 3, 43-120. USSR Academy of Sciences. (In Russian).

Péwé, T. L. (1955). Origin of the upland silt Near Fairbanks, Alaska. Bull. Geol. Soc. Am. 67, 699-724.

Péwé, T. L. (1975). Quaternary Geology of Alaska. U.S. Geological Survey professional paper 835. Washington D.C.: United States Government Printing Office.

Popov, A. I. (1952). Frost Cracking and Problems of Fossil Ice. Permafrost in Different Parts of the USSR. Proc. Obruchev Permafrost Inst. IX, 81-89. (In Russian).

Popov, A. I. (1967). Cryogenic Phenomena in the Earth Crust (Cryolithology). Moscow: Moscow University Press. (in Russian).

Porsild, A. E. (1938). Earth Mounds in Unglaciated Arctic Northwestern America. Geographical Rev. 28 (No. 1), 46-58. doi:10.2307/210565

Prindle, L. M., Katz, F. J., and Smith, P. S. (1913). A Geological Reconnaissance of the Fairbanks Quadrangle, Alaska. United States Geol. Surv. Bull.. Washington: Government Printing Office, 525.

Quackenbush, L. S. (1909). Notes of Alaskan mammoth Expeditions of 1907 and 1908. Bull. Am. Mus. Nat. Hist. 26, 87-130.

Richardson, J. (1854). in The Zoology of the Voyage of H.M.S. Herald, under the Command of Captain Henry Kellett, R.N., C.B., during the Years 1845-51. London: Reeve and Co, Vol. III.

Romanovskii, N. N. (1958). Paleogeographic Conditions for the Formation of Quaternary Deposits on Bol'shoy Lyakhovsky Island (New Siberian Islands). Issues Phys. Geogr. polar countries 1, 68-81. (in Russian).

Russell, I. C. (1890). Notes on the Surface Geology of Alaska. Bull. Geol. Soc. Am. 1, 99-162. doi:10.1130/gsab-1-99

Saks, V. N. (1947). Quaternary Glaciation of Siberia. Nature (Priroda) 4, 16-25. (In Russian).

Schirrmeister, L., Froese, D., Tumskoy, V., Grosse, G., and Wetterich, S. (2013). "PERMAFROST and PERIGLACIAL FEATURES | Yedoma: Late Pleistocene Ice-Rich Syngenetic Permafrost of Beringia," in Encyclopedia of Quaternary Sciences. Editors S. A. Elias and C. J. Mock. Second edition (Amsterdam: Elsevier), 2, 542-552. doi:10.1016/b978-0-444-53643-3.00106-0

Seemann, B. (1853). Narrative of the Voyage of H.M.S. Herald, under the Command of Captain Henry Kellett, R.N., C.B., during the Years 1845-51. London: Reeve and Co, Vol. II.

Sellmann, P. V. (1967). Geology of the USA CRREL Permafrost Tunnel, Fairbanks, Alaska. Hanover, New Hampshire: US Army CRREL. Technical Report 199.
Sheinkman, V. S. (2017). Glaciation of Siberia and the Problem of Massive Ice Beddings. Ice and Snow (Lyod i Sneg) 57 (4), 527-542. (in Russian). doi:10.15356/2076-6734-2017-4-527-542

Sher, A. V. (1997). "Yedoma as a Store of Paleoenvironmental Records in Beringia," in Beringia Paleoenvironmental Workshop, Florissant, CO, September 20-23, 1997, Abstracts and Program. Editors S. Elias and J. Brigham-Grette, 92-94.

Shumskii, P. A. (1952). "Studies of Fossil Ice in Central Yakutia," in Permafrost Research in Republic of Yakutia (Moscow: USSR Academy of Sciences), 3, 142-161. (In Russian).

Shumskii, P. A. (1959). "Underground Ice," in Fundamentals of Geocryology (Permafrost Science), Part 1 General Geocryology. Editors P. F. Shvetsov and B. A. Dostovalov (Moscow: USSR Academy of Sciences), 274-327. (In Russian).

Shumskii, P. A. (1960). "On Genesis of Wedge Underground Ice," in Collection of Articles on General Permafrost Studies. Proceedings of Obruchev Permafrost Institute. Editor A. I. Efimov (Moscow: USSR Academy of Sciences), Vol. 16. (In Russian).

Shumskii, P. A., Shvetsov, P. F., and Dostovalov, B. N. (1955). Peculiarities of Geotechnical Investigations in the Areas with Underground Wedge Ice. Moscow: USSR Academy of Sciences. (In Russian).

Smith, P. S. (1993). The Noatak-Kobuk Region Alaska. Washington: United States Geological Survey, Bulletin, 536.

Solomatin, V. I. (1986). Petrogenesis of Underground Ice. Novosibirsk: Nauka. (In Russian).

Sörgel, W. (1936). Diluviale Eiskeile (Diluvial Ice Wedges). Z. der Deutschen Geologischen Gesellschaft 88, 223-247. (In German).

Strauss, J., Laboor, S., Schirrmeister, L., Fedorov, A. N., Fortier, D., FroeseFuchs, D. M., et al. (2021). Circum-Arctic Map of the Yedoma Permafrost Domain. Front. Earth Sci. 9. doi:10.3389/feart.2021.758360

Sumgin, M. I. (1927). Permafrost in USSR. Moscow-Leningrad: USSR Academy of Sciences. (In Russian).

Taber, S. (1930). The Mechanics of Frost Heaving. J. Geology. 38 (4), 303-317. doi: $10.1086 / 623720$

Taber, S. (1943). Perennially Frozen Ground in Alaska: its Origin and History. Geol. Soc. America Bull. 54 (10), 1433-1548. doi:10.1130/gsab-54-1433

Tolmachev, I. P. (1903). "Ground Ice from the Berezovka River (In Northeast Siberia)," in Scientific Results of the Expedition Sent by Imperial Academy of Sciences to Excavate a mammoth Found at the Berezovka River in 1901 (SanktPeterburg: Imperial Academy of Sciences), Vol. 1, 125-139. (In Russian).

Tolmachev, I. P. (1906). News from Khatanga Expedition under Command of Tolmachev (From a Letter to Chernyshev). Proc. Imperial Russ. Geographical Soc. XLII, 785-796. (In Russian).

Tolmachev, I. P. (1911). Along the Chukchi Coastline of the Arctic Ocean. SanktPeterburg: Economic Typo-Lithography. (In Russian).

Tolmachev, I. P. (1928). "The Geology of Arctic Eurasia and its Unsolved Problems," in Problems of Polar Research. Editor W. L. G. Joerg (New York: American Geographical Society), 75-90.

Tolmachoff, I. P. (1929). "The Carcasses of the Mammoth and Rhinoceros Found in the Frozen Ground of Siberia," in Transactions of the American Philosophical Society New Ser. (Philadelphia: The American Philosophical Society), Vol. 23, 1.

Tomirdiaro, S. V. (1978). in Permafrost Second International Conference July 13-28, 1973, USSR Contributions (Washington, D.C: National Academy of Sciences), 817-819.Cryogenic-Aeolian Genesis of Yedoma deposit

Tuck, R. (1940). Origin of the Muck-silt Deposits at Fairbanks, Alaska, 51. Bulletin of the Geological Society of America, 1295-1310. Geological Society of America Bulletin. doi:10.1130/gsab-51-1295

Turner, L. M. (1886). Contributions to the Natural History of Alaska. Washington: U. S. Army No. II. Government printing office. Arctic series of publications issued in connection with the signal service.

Tyrrell, J. B. (1904). Crystosphenes or Buried Sheets of Ice in the Tundra of Northern America. J. Geol. 12 (3), 232-236.

Tyrrell, J. B. (1917). Frozen Muck in the Klondike District, Ser. 3, V. 11. Ottawa: Transactions of the Royal Society of Canada, 39-46.Section IV.

van Everdingen, R.O. (Editor) (1998). Multi-Language Glossary of Permafrost and Related Ground-Ice Terms (Calgary: University of Calgary).

Vasil'chuk, Yu. K. (2012). "Classification of Massive Ice," in Proceedings of the Tenth International Conference on Permafrost, June 25-29, 2012, Salekhard, Russia. Editors V. P. Melnikov, D. S. Drozdov, and V. E. Romanovsky (Salekhard, Russia: The Northern Publisher), Vol. 2, 493-497. 
Vollosovich, K. A. (1909). Recovering of Sanga-Yuryakh mammoth. Proc. Imperial Acad. Sci. Part 633, 437-458. (In Russian).

Vollosovich, K. A. (1915). Mammoth of Bol'shoy Lyakhovsky Island. Proc. Mineralogical Soc. 50, 305-338. (In Russian).

von Baer, K. M. (1842). Notes for a Study of Ground Ice in Siberia. Russian translation of the manuscript. Sankt-Peterburg - Moscow - Yakutsk: Mel'nikov Permafrost Institute, 2000. (in Russian).

von Bunge, A. A. (1883). "Natural History News from the Polar Station at the Mouth of the Lena River. From a Letter to the Academician L.V. Schrenck," in Bulletin of the Imperial Academy of Sciences (St. Petersburg: Imperial Academy of Sciences), Vol. X1, 581-622. (In German).

von Bunge, A. A. (1887). "Bericht über den ferneren Gang der Expedition. Reise nach den Neusibirischen Inseln. Aufenthalt auf der Großen Ljachof-Insel," in Expedition zu den Neusibirischen Inseln und dem Jana-Lande (1885). Editors L. V. Schrenk and C. J. Maximovicz (St. Petersburg: Commissionare der Kaiserlichen Akademie der Wissenschaften), Vol. III, 231-284. Beiträge zur Kenntnis des russischen Reiches und der angrenzenden Länder. (In German). von Bunge, A. A. (1895). "The Lena Expedition 1881-1884," in Observations of the Russian Polar Station at the Lena Mouth. Editors A. Tillo and A. Tillo (St. Petersburg: Russian Geographical Society), 1-96. Beobachtungen der russischen Polarstation an der Lenamündung. Expedition der Kaiserlichen Russischen Geographischen Gesellschaft. (In German).

von Bunge, A. A. (1903). Einige Worte zur Bodeneisfrage. Proc. Imperial St. Petersburg Mineralogic Soc. ser. 40, 203-209. (In German).

von Chamisso, A. (1821). "Remarks and Opinions, of the Naturalist of the Expedition," in A voyage of Discovery into the South Sea and Beering's straits, for the purpose of exploring a north-east passage, undertaken in the years 1815-1818, at the expense of His Highness the Chancellor of the Empire, Count Romanzoff, in the ship Rurick, under the command of the lieutenant in the Russian Imperial Navy, Otto von Kotzebue (London: Longman, Hurst, Rees, Orme, and Brown), Vol. 3.

von Chamisso, A. (1836). A Voyage Around the World with the Romanzov Exploring Expedition in the Years 1815-1818 in the Brig Rurik (English Translation). Honolulu: University of Hawaii Press.

von Hedenström, M. (1830). Excerpts on Siberia. Sankt-Peterburg: Medical Department of Ministry of Internal Affairs. (In Russian).

von Kotzebue, O. (1821). A voyage of Discovery into the South Sea and Beering's straits, for the purpose of exploring a north-east passage, undertaken in the years 1815-1818, at the expense of His Highness the Chancellor of the Empire, Count Romanzoff, in the ship Rurick, under the command of the lieutenant in the Russian Imperial Navy, Otto von Kotzebue, Vol. 1. London: Longman, Hurst, Rees, Orme, and Brown.

von Maydel, G. (1894). Journey in north-west Yakutia in 1868-1870. Appendix to LXXIV Notes of Imperial Academy of Sciences. St. Petersburg: Imperial Academy of Sciences.

von Middendorff, A. T. (1860). "Orographie und Geognosie," in Dr. A. Th. v. Middendorff's Sibirische Reise. Übersicht der Natur Nord- und Ost-Sibiriens. Editor A. T. von Middendorff (St. Petersburg: Kaiserliche Akademie der Wissenschaften), 201-332. Bd. 4, Th. 1, Lieferung 2. S. (In German).

von Toll, E. V. (1891). "Ueber die Wechselbeziehungen zwischen dem Steineise, der Eiszeit und dem Mammut Neusibiriens," in Verhandlungen des neunten deutschen Geographentages zu Wien (Berlin: Verlag von Dietrich Reimer), 53-64. (In German). von Toll, E. V. (1895). Wissenschaftliche Resultate der von der Kaiserlichen Akademie der Wissenschaften zur Erforschung des Janalandes und der Neusibirischen Inseln in den Jahren 1885 und 1886 ausgesandten Expedition. Abtheilung 3. Die fossilen Eislager und ihre Beziehungen $z u$ den Mammuthleichen. Mémoires de L'Académie impérials des Sciences de St. Pétersbourg VII Série, Tome XLII, No. 13. St. Petersbourg: Commissionnaires de I'Académie Impériale des Sciences, 1-86. (In German). von Toll, E. V. (1897). Fossil Glaciers on New Siberian Islands and Their Relation to Corps of Mammoths and to the Ice Age. St. Petersburg: Imperial Academy of Sciences. (In Russian).

von Toll, E. V. (1959). Sailing on the yacht "Zaria". Editor P. V. Wittenburg (Moscow: Geographical Literature). (In Russian).

Vtyurin, B. I. (1955). Underground Ice. Structure, Genesis, and Areas of Occurrence of Big Masses of Underground Ice and its Geomorphic Significance. Moscow: Ph.D. thesis. Moscow State University. (In Russian).

Wilkerson, A. S. (1932). Some Frozen Deposits in the Goldfields of Interior Alaska a Study of the Pleistocene Deposits of Alaska. New York: American Museum Novitates, No 525, American Museum of Natural History.

Williams, J. R. (1962). Geologic Reconnaissance of the Yukon Flats District, Alaska. Washington, DC: U.S. Geological Survey Bulletin 111-H, 290-311.

Wittenburg, P. V. (1959). Introduction to von Toll's Diary (Sailing on the yacht "Zaria"). Moscow: Geographical Literature, 3-6. (In Russian).

Wrangel, F. (1841). Journey along Northern Shore of Siberia and Ice Sea. Part 2. Sankt-Peterburg. (In Russian).

Zhestkova, T. N., Shvetsov, P. F., and Shur, Y. L. (1982). in Yedoma, a Climatic Formation (Moscow: XI Congress of International Union for Quaternary Research), Vol. II, 389. . Abstracts. (In Russian).

Zhestkova, T. N., Shvetsov, P. F., and Shur, Y. L. (1986). "On Genesis of Yedoma," in Geocryology Studies. Editor E. D. Ershov (Moscow: Moscow State University), 108-113. (In Russian).

Conflict of Interest: Author MJ owns company Alaska Ecoscience. The remaining authors declare that the research was conducted in the absence of any commercial or financial relationships that could be construed as a potential conflict of interest.

The handling editor is currently organizing a Research Topic with one of theauthors LS.

Publisher's Note: All claims expressed in this article are solely those of the authors and do not necessarily represent those of their affiliated organizations, or those of the publisher, the editors and the reviewers. Any product that may be evaluated in this article, or claim that may be made by its manufacturer, is not guaranteed or endorsed by the publisher.

Copyright (c) 2022 Shur, Fortier, Jorgenson, Kanevskiy, Schirrmeister, Strauss, Vasiliev and Ward Jones. This is an open-access article distributed under the terms of the Creative Commons Attribution License (CC BY). The use, distribution or reproduction in other forums is permitted, provided the original author(s) and the copyright owner(s) are credited and that the original publication in this journal is cited, in accordance with accepted academic practice. No use, distribution or reproduction is permitted which does not comply with these terms. 